\title{
The Place of the Holy Man in the Later Roman Empire
}

\author{
Ramsay MacMullen \\ Yale University; email: ramsay.macmullen@yale.edu
}

\section{Abstract}

The early centuries in the history of Christian asceticism, and of monasticism to which it gave rise, invite a short and accessible overview. The present article aims to supply this. It relies on a very large sampling of texts, mostly hagiographic. As ascetics are there to be seen described by contemporaries and near-contemporaries, they share many traits which can be grouped under principal headings and frequency of mention. A statistical profile emerges, presented under numerous headings and totals which in turn indicates the ascetics' most salient aims and acts, and helps to explain the course of development of their institutions. The findings challenge a still-famous and almost universally accepted overview offered by Peter Brown (1971). This the present article seeks to replace at the outset, through calling in question Brown's methodological assumptions, and second, in its closing pages, through challenging Brown's picture of the holy man in other, more factual points.

\section{Key Words}

ascetics, monasticism, hagiography, miracle-working

\section{Introduction}

Given the impact of early Christian asceticism on later events, institutions, and developments in the West to which it gave rise, no wonder there has been so much interest in the subject. Students trained in classical philology or theology, or both together, or in archeology, have certainly had their say about it. For historians, however, it is a prime rule of art (not to mention, a rule of common sense) that 
whatever one says about the past should rest on a data-base of matching size; if it's a broad statement or generalization, nothing less than lots of supporting facts and instances will do. It is my aim, here, to show how this rule may be applied to the study of the holy man.

\section{Mistaken Method and Its Costs}

The importance of the rule can be illustrated through Peter Brown's essay on my subject appearing in the journal at the center of Roman studies for over a century: the venerable JRS, in its web-site advertising Brown's article as its most famous publication. ${ }^{1}$ There (its page-numbers in parentheses) he accounts for the appearance of the holy man on the stage of history by positing two "crises." The first, cultural (99), was the "religious revolution" of the Roman Empire in Late Antiquity (99, thrice; 93; and 100). This revolution, however, was not the victory of Christianity over polytheism in itself (100); the essence of it was rather "the rise of the holy man," constituting a "leitmotiv" (99), which happened to "coincide" with the "natural death" of polytheism (100) and of the polytheists' belief in "divinity" and "great temples" $(98,99) .^{2}$ Into the place and faith that had been the gods' for so long $(93)$ now stepped this new being in a crucial role, thanks to his ascendancy, attaining "such eminence" (81). "The predominance of the holy man" can even be taken as a boundary-marker to distinguish "late antiquity as a distinct phase" in history (100).

The flow of explanation here is presented in sweeping terms, descriptive of the entire empire (81-82) and its fifty or sixty millions. Historians and their readers are of course familiar with broad-brush statements serving the flow of an argument if the underpinning has been properly established through conventional treatment, that is, with adequate challenges and response and proportionate documentation. A person trained in languages and literature may be less demanding. ${ }^{3}$ Brown takes as his admired "model" the work of E. R. Dodds a few years prior, where the mind of "the West," that is, of the Roman Empire, is to be read through the writings of the intellectual elite and of no more than nine or ten among them scattered across more than four hundred years. Their readership cannot be imagined above a few thousand

${ }^{1}$ Peter Brown, "The Rise and Function of the Holy Man in Late Antiquity," Journal of Roman Studies 61 (1971) 80-101.

${ }^{2}$ For this "natural death" Brown offers no support, only assertion; but a scenario quite the opposite is suggested by Ramsay MacMullen, Christianity and Paganism in the Fourth to Eighth Centuries (New Haven: Yale University Press, 1997).

${ }^{3}$ The difference between a historian's and a classicist's style of thought is highlighted by Brown's warm admirer, James Howard-Johnston, "Introduction," The Cult of Saints in Late Antiquity and the Early Middle Ages: Essays on the Contribution of Peter Brown (ed. James Howard-Johnston and Paul Antony Hayward; Oxford: Oxford University Press, 1999) 1-26, at 14, finding Brown's essay reminiscent of John Constable's paintings of "ever-varying cloud formations." For a critical assessment, see rather Mark Sheridan OSB, From the Nile to the Rhone and Beyond: Studies in Early Monastic Literature and Scriptural Interpretation (Roma: Pontificio Ateneo S. Anselmo, 2012) 173-74, protesting against Brown's "sweeping generalization" about private-life morals, in his later publications, which can hardly "be called 'history' . . . the interpretation overwhelms the evidence." 
in any decade. This sampling, however, is used to justify a general conclusion that some half-billion persons were noticeably anxious across this very considerable stretch of time. ${ }^{4}$ Unsupported, how can this proposition be taken seriously?

As to what the holy man did - his function in society - it was to fill a gap in local leadership. Brown discerns a second "crisis," a profound change in the relations of dependency and influence or power binding together the Have-nots and the Haves. He detects "a seismic shift in social relations" induced by "rising prosperity" (87), in turn producing a "crisis of leadership" (85), to be remarked in "the tendencies of later Roman agricultural life" (90). It is a turning point transforming the whole "Roman world," "the later Roman empire," "the empire" as a whole $(86,87)$, its society (99), and general human "needs" in "the Later Empire" (92, 93). "It is precisely at this point that the holy man comes to the fore as a figure in village society and in the relation between the village and the outside world" (87). It is a "crisis," however, like the cultural one, above, that has somehow escaped notice. If the two crises cannot be established, it is not easy to see how they can serve as the foundation for further argument and understanding.

The fact remains, however, that Brown's essay still represents the scholarly consensus, at least in English. ${ }^{5}$ It is thus no antiquarian whim that prompts my critical interest in it and my attempt to sketch out something better. ${ }^{6}$

\footnotetext{
${ }^{4}$ The population dealt with is that of the empire, times the number of generations within a century, that is, something over two. The writers discussed ranged from Aelius Aristides to Boethius, in Eric Robertson Dodds' Pagan and Christian in an Age of Anxiety (Cambridge: Cambridge University Press, 1965), serving discussion of a "wave of pessimism that swept over the West" (18, see 26), accounting for "all this madness" of ascetic enthusiasm (33-34, 46-47), and taken as "a model" by Brown, "S[ymbolae] O[sloenses] Debate: The World of Late Antiquity Revisited," SO 72 (1997) 19; see Brown's review of Dodds' book, finding it "a masterpiece of precise analysis," in the $E H R$ 83 (1968) 543.

${ }^{5}$ Exceptional, but passed over among Anglophone scholars of the early Church, is the essay focused on Egypt by Françoise Dunand, "Syncretismi et forme della vita religiosa," I Greci. Storia Cultura Arte Società (ed. Salvatore Settis; Turin: Einaudi, 1998) 2,3: 335-78, made use of below at n. 36.

${ }^{6}$ Referring to Peter Brown's essay "Rise and Function," Glen W. Bowersock, "The Vanishing Paradigm of the Fall of Rome," Bull. Am. Acad. Arts Sci. 49. 8 (1996) 27-43, at 47, called the essay "an immensely important paper," quoting Ihor Sevcenko, leading Byzantinist of the time, who hailed it as "the Big Bang"; among early converts, see Hans J. W. Drijvers, "Hellenistic and Oriental Origins," East of Antioch: Studies in Early Syriac Christianity (ed. Hans J. W. Drijvers; London: Variorum Reprints, 1984) 25-33, at 25-26; the author himself called it "an academic breakthrough," see Peter Brown, "The Rise and Function of the Holy Man in Late Antiquity, 1971-1997," JECS 6 (1998) 353-75, at 358; further, Susanna Elm, "Introduction," JECS 6 (1998) 343-51, at 343-44, seeing the article as "electrifying . . . a paradigm shift . . . a lightning bolt," with synopsis 346; Andrew Howard-Johnston, "Introduction," Cult of Saints 1-24, at 3-4, synopsis, terming Brown "the Master" (4, 8, and 24); Averil Cameron, "On Defining the Holy Man," Cult of Saints 27-43, at 27, "seminal"; Claudia Rapp, "For next to God, you are my salvation': Reflections on the Rise of the Holy Man in Late Antiquity," Cult of Saints 63-81, at 65, where the holy man attracts "clients," he is their "patronus and an arbiter. This is the model put forward by Peter Brown in his seminal article." Further, Tim Vivian, 'Histories of the Monks of Upper Egypt' and 'The Life of Onnophrius' by Paphnutius with 'A Discourse on Saint Onnophrius' by Pisentius of Coptos, Translated with Introduction (Kalamazoo: Cistercian Publications, 2000) 31, "seminal discussion
} 
Further criticisms may be left for my concluding pages, since constraints on the length of my own essay prevent a review of prior scholarship. My notes and an appendix must suffice. But at the outset of my alternative treatment, I do draw attention to my intended focus, not on ascetical experiences so much discussed, but on what contemporaries and near-contemporaries observed from the outside and wondered at in the behavior of the holy man. This, his "external" history as opposed to "internal," is what Brown focuses on also: "the role of the holy man. . . his position" (80), his historical importance.

\section{Ideas Governing Ascetic Routines}

The earliest holy man known by name was Antony "of the desert." In his late teens, he is said to have discovered ascetics already living a solitary life away from their villages in his part of Egypt. They had evidently been settled in the area from the mid-third century. Others like them were in time established elsewhere throughout the Fertile Crescent, from Cairo to northern Mesopotamia, some ordained as bishops like Rabbula of Edessa or Theodore of Dara; some to Constantinople with Daniel the Stylite among others. This much defines my subject in space; the sources in my Appendix define the period studied, roughly from 275 to 575.

As to the region, it had a distinct character in regard to asceticism as in other ways. This disciplined manner of life had long attracted favorable notice. It was a dictum of a very traditional non-Christian that "the one who loves god cannot love pleasure or body."7 In Christian times, post-Constantine, "ascetics" - the term used interchangeably for holy men in modern treatments - were also called "devotees" (that is, of God) by their neighbors, both terms being applied to them in

of the holy man"; Silke Trzcionka, Magic and the Supernatural in Fourth-Century Syria (London/ New York: Routledge, 2007) 32-33; Elizabeth A. Clark, "From Patristics to Early Christian Studies," Oxford Handbook of Early Christian Studies (ed. Susan Ashbrook Harvey and David G. Hunter; Oxford: Oxford University Press, 2008) 14-22, at 20, "Brown's now classic article"; Rebecca Krawiec, "Asceticism," Oxford Handbook 764-86, at 770, it "transformed hagiography"; Cam Grey, Constructing Communities in the Late Roman Countryside (Cambridge: Cambridge University Press, 2011) 131, Brown's article is "the locus classicus," with a synopsis of its main findings; Fergus Millar, Empire, Church and Society in the Late Roman Near East: Greeks, Jews, Syrians and Saracens (Collected Studies 2004-2014) (Leuven/ Paris/ Bristol, CT: Peeters, 2015) 271, "classic portrait of the Near Eastern holy man," from which Millar, however, differs in important ways; and Rita Lizzi Testa, "Introduction," Late Antiquity in Contemporary Debate (ed. Rita Lizzi Testa; Newcastle upon Tyne: Cambridge Scholars Publishing, 2017) vi-xlix, at xxx, from Brown's article singling out the role of the patron to define the holy man.

${ }^{7}$ Aside from common pre-Christian strictures against recent sexual intercourse before acts of worship, notice Philostratus, Vita Apollonii 7-8, and other passages in Ramsay MacMullen, Paganism in the Roman Empire (New Haven: Yale University Press, 1981) 43, 55, 63 (quoted, Porphyry), 166 n. 7, and 191 n. 5; further, with several biographies examined, Drijvers, "Hellenistic," at various points; and much discussion of Hellenistic and early Christian views, for example in Philippe Escolan, Monachisme syrien du $I V^{e}$ au VII siècle: un ministère charismatique (Paris: Beauchesne, 1999) 65-69 and elsewhere; in agreement, Richard Finn OP, Asceticism in the Graeco-Roman World (Cambridge: Cambridge University Press, 2009) 154. 
a letter of the 340s to a certain Paphnutius and further explained by another term, philoi, applied more often by Greek-speakers to "adherents" and "supporters" in secular contexts; and this meaning underlay still another term very common among ascetics for one of themselves, philotheos, "God-devoted" (the chummy translation, "Friend of God," misreads the Greek). ${ }^{8}$ Individuals like these, from a few score at their earliest mention, grew in numbers through the attraction of followers and the formation of them into communities throughout the Fertile Crescent, eventually to a considerable total. A good handful of exact figures about them survive. These are offered by contemporaries in self-definition, obviously rounded but most of them not implausible. They suggest an aggregation over the course of my three chosen centuries amounting to some hundreds of thousands in communities mostly of monks; some, of nuns. ${ }^{9}$

Describing ascetics brought to our attention, almost all by name, there also survive at least a few lines for their characterization or anecdotes, or more, into the tens or scores of pages, for more than 170 of them. An appendix indicates the individuals considered here, a majority found in John of Ephesus, in Palladius' Lausiac History with 16 more non-duplicative in the History of the Monks in Egypt, still more in Paphnutius' Histories, and smaller numbers to be found scattered through other texts.

The governing idea among them was a fear-full thing, spurred by the fourth beatitude, "blessed are the sorrowful." Sorrow for one's irremediable faults was expressed in a thousand practices or fragments of self-explanation: for example, "I am bent down beneath many sins, and, believing in the threatened punishments, I

${ }^{8}$ See the often quoted mid-fourth century letter to an anchorite, Paphnutius, he being one of

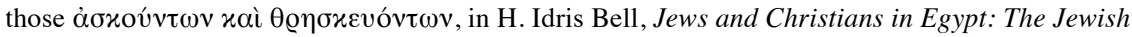
Troubles in Alexandria and the Athanasian Controversy (London: British Museum, 1924) 108-9, No. 1926; on $\phi \iota \lambda o ́ \theta \varepsilon o \varsigma$, for example, in Eusebius, Vita Const. 49, see the correct meaning "devoted to" or "loving," rather than "loved by" or "friend of" God, as is pointed out by, for example, Gerhardus Johannes Marinus Bartelink, Athanase d'Alexandrie, Vie d'Antoine, Introduction, texte, traduction (Paris: Cerf, 1994) 141; sometimes the term, ó $\tau \hat{\omega} \theta \varepsilon \hat{\omega} \phi \iota \lambda$ ós, devoted to God; but giving an idea

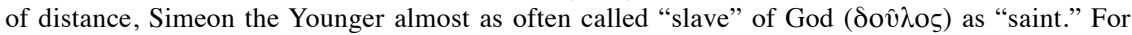
modern usage "ascetic" = "holy man," see, for example, Brown, "Rise and Function" 82, 83, 84, 91, 93; James E. Goehring, Ascetics, Society, and the Desert: Studies in Early Egyptian Monasticism (Harrisburg, PA: Trinity Press International, 1999) 21 and elsewhere; or Millar, Empire, 271; for not only ascetics but also cenobites and monks as "holy men," see, for example, Philip Rousseau, Ascetics, Authority, and the Church in the Age of Jerome and Cassian (Notre Dame, IN: University of Notre Dame Press, 1978 [2nd ed., 2010]) xix, the Introduction; and on the early institutionalizing of asceticism in Egypt, Sheridan, From the Nile, 48-49, 242-49.

${ }^{9}$ Among many scattered ascetic-census mentions, see, for example, Theodoret, Hist. relig. 3.4 (400 in two monasteries); 30.4 (a nunnery with 250); in the Vita Hypatii 11.1, in Chalcedon, "many" monasteries, one with 150 monks; and to these figures, add those collected by Arnold Hugh Martin Jones, The Later Roman Empire, 284-602: A Social Economic and Administrative Survey (Norman, OK: University of Oklahoma Press, 1964) 930-31. In Egypt alone, in the years around 450-500, he finds above 60,000 , though warning against exaggerations. Depending on life-expectancy estimates, there would be above 2 generations per century, therefore in three centuries in Egypt alone, my suggested total or much more, since all other provinces of the Near East must be considered also. 
have conceived this manner of life and invented its pains, so far as I could endure them, so as to reduce the weight of punishments I can foresee." So a certain Thalelaios tells his visitors. As another says, "I have spent forty years in this cell caring for my salvation"; another says, "I am an ocean of sins"; similarly, the voice of a penitent for a full thirty years, whose "wailings throughout the night left his neighbors no peace." 10

No worshipper who took such convictions to heart could simply ignore them; but response that could be rightly called theophilia, "devotion," was as various as one can imagine. Denial of normal physical needs and impulses was always an individual matter, modified by the physical environment, sometimes with self-hurt superadded in one form or another, sometimes unambitious, sometimes nearly lethal. Hermits in their little cells tried to minimize human contacts, seen as temptations to misconduct, and distractions from prayer or other worshipful practices; they might choose even to accentuate their isolation by having themselves walled in, leaving only a little window for conversation's sake and sustenance. Complete isolation, however, might yield to the sharing of religious meals and services in loosely clustered groups; and even for hermits, help from a local village was needed for the supply of food and drink in exchange for simple manufactures, baskets or rope. Sometimes, too, ascetics made visits to others of their kind or to a city, even long residence there. The more celebrated were often under pressure from church authorities to be engaged more fully in lay society, and so, to be ordained as priests or monastery-heads (higoumenoi), to serve as head of many monasteries (archimandrites) or even as bishops; and they reluctantly or willingly took on such official duties. Sometimes like Pachomius they maintained the rigor of their ascesis undiminished. "The ascetic movement" as it is sometimes called thus could lead into many various careers.

\section{Ascetics' Relations with Lay Society}

As to their place in lay society as a whole, one group of holy men chose to court crowds and fame itself through their extraordinary routines of supplication. In the district near Beroea (Aleppo) in a local, pre-Christian tradition, ascetics went to the length of perching themselves atop pillars thereby better to seek aid from on

${ }^{10}$ For a fine collection of statements of and about the remorse of eastern-empire $\pi \varepsilon v \theta 0 v 0 v \varepsilon \varsigma$ (Matt 5:4), see Irénée Hausherr, PENTHOS. La doctrine de la compunction dans l'Orient chrétien (Roma: Pont. Institutum Orientalium Studiorum, 1944), at various points. The first quoted statement is by a certain Thalelaios/Thallelaeus of Gabala near Syrian Laodicea, in Theodoret, Hist. relig. 28.4, in Théodoret de Cyr, Histoire des moines de Syrie 'Histoire philothée,' Introduction, texte critique, traduction et notes (ed. Pierre Canivet and Alice Leroy-Molinghen; 2 vols.; Paris: Cerf, 1977-79) 2. 228-29; the second declaration by a certain Pachon, Hist. relig. 23.3; the third, by Simeon Stylites, in his Life 7, see Robert Doran S. J., The Lives of Simeon Stylites (Kalamazoo, MI: Cistercian Publications, 1992) 90; the third in the life of Aphrodisius, see Cyril of Scythopolis: Lives of the Monks of Palestine (trans. Richard M. Price; Kalamazoo, MI: Cistercian Publications, 1991) 144; a fourth, "sit in your cell and weep for your sins," quoted from the Apophthegmata in Rousseau, Ascetics, 44. 
high for petitioners below. Their ambition found a match in Christian doctrines of that region, later personified in the stylite saints. In the shaping of their lives for acclaim, these Syrians differed from their Egyptian brothers; they remained a tiny if spectacular minority, and the doctrine supporting them, a theoretical thing without effect on the governing ideas of the ascetic movement elsewhere. ${ }^{11}$

For the generality of them, the rules of life were surprisingly uniform across all of the region, making it difficult for the modern reader unassisted by some give-away detail to guess whether an individual receiving biographical treatment was mostly based in Palestine or (modern) Iraq, Syria or Egypt. ${ }^{12}$ This degree of uniformity can be explained partly by the annual or almost annual meetings of the church hierarchy in its provincial councils, and exchanging information, but more, by the traveling about or emigrating and re-settling of disciples and the more confident and educated solitaries, occasionally whole monkish communities, from one place to another, not always welcome but making a place for themselves.

Among all the populations of the Fertile Crescent where the phenomenon originated, we find attested in documents of the second millennium down to the period of my focus two further governing ideas long known at least among scholars. These were, first, a social ethic, that is, a set of beliefs about how to behave toward persons in need, the Haves toward the Have-nots; and second, acceptance of demonic causation thought to underlie afflictions of any sort, most especially of one's health. The first of these two ideas was communicated from the top down to the subjects of early monarchies in the region, including those smaller kingdoms overwhelmed by conquest in the Holy Land, where it was embodied in so-called Wisdom Literature, Jewish moral teachings, and eventually in the teachings of Jesus. ${ }^{13}$ As to the second idea, demonic causation, over those same millennia

${ }^{11}$ Lucian, Dea Syria, 29; compare Ernest Walter Brooks, John of Ephesus, Lives of the Eastern Saints: Syriac Text Edited and Translated (Paris: Brepols, 2003 [1923-1925]) 57 §4, where the ascetic Abraham who mounts a pillar thereby receives "the gifts of the spirit." For the pagination of this work, see the entry below in the Appendix. The general belief that there is a connection between Lucian's account and pillar-saints is noted but resisted by Hippolyte Delehaye, Les saints stylites (Brussels: Société des Bollandistes, 1923) 177-85, and similarly without engaging with the Lucian evidence, by mere dismissal, in, for example, Paul van den Ven, La vie ancienne de S. Syméon stylite le Jeune (Brussels: Société des Bollandistes, 1962-1970) 1.132. For a survey of pillar-saints of the 6th-9th centuries (87 of them!), see Lukas Amadeus Schachner, "The Archeology of the Stylite," in Religious Diversity in Late Antiquity (ed. David M. Gwyn and Susanne Bangert; Leiden/ Boston: Brill, 2010) 382 and elsewhere.

${ }^{12}$ A degree of uniformity of practice across the Fertile Crescent, good enough to treat it all as one thing, is assumed by Millar, Empire, 271, as by myself, and by Brown, "Rise and Function," 91 and elsewhere. Notice Soz., Hist. eccl. 1.13 (PG 67.900B), Antony's disciples each "teaching many others" in Libya, Egypt, Syria, Palestine, and Arabia. On the variant sect of Messalians, however, see below at $\mathrm{n} .64$.

${ }^{13}$ The derivation of this ethic is plain in the sources, as has long been established, though it is not likely to appear in modern accounts of Judaism or Christianity; see Ramsay MacMullen, "Social Ethic Models: Roman, Greek, 'Oriental," Historia 64 (2015) 487-510; for the model not only in OT texts but in the thoughts of ascetics, see, for example, the scriptural citations in the Life of Theodore of Sykeon 147 (Job 29:12 and Ps 82:4). 
there had been, or was, hardly a doubt anywhere that supernatural beings, most often malevolent, were the agents behind plagues and famines or storms at sea on a grand scale, as also on a small scale serving to explain a malformed limb, infertility, paralysis, recurrent fever, depression, scoliosis, or the like. ${ }^{14}$ The first Christian holy man explains, in words assigned to him by his biographer, what everyone believed anyway: Evil spirits are everywhere, filling the air we breathe, close besetting us all. ${ }^{15}$

One could only bring one's serious problems to some supernatural agent(s), for help. Home-medicines and wise women had failed. We have abundant testimony of prayers, of which there survive many hundreds in the period of interest to me; but of these, only a small number indicate just what supplication or thanks were for, whether in inscriptions, or carven thank-offerings, supplicant letters, or literary mentions in various genres. No data-base has been attempted in any good fashion, to my knowledge. Quite numerous prayer-texts are scratched on walls beneath Saint Peter's basilica; eastern provinces provide representations of afflicted body-parts, letters to holy men on papyri, lists from martyrs' shrines, wives worried about absent husbands or generals about some coming campaign, in biographies; mentions, too, in other types of written document. ${ }^{16}$ All these causes of anxiety are to be added

${ }^{14}$ Most broadly, see Morton Smith, Jesus the Magician (New York: Harper and Row, 1978) 4 and elsewhere; Luigi Leone, Gregorio di Nissa, Vita di Gregorio Taumaturgo. Traduzione, introduzione e note (Roma: Città nuova editrice, 1988) 20; MacMullen, "Social ethic models," 491 n. 17; specifically on health matters, 491, 501-4; André-Jean Festugière, "Épidémies 'hippocratiques' et épidémies démoniques," Wiener Studien 79 (1966) 157-64; Vie de Théodore de Sykeon (ed. André-Jean Festugière; 2 vols.; Brussels: Société des Bollandistes, 1970) 1: xviii-xxiv; and hundreds of references suggested in the Appendix, below, for example, in the Life of Hypatius 15.2 or 28.7-12, see Vida de Hipacio, Calinico, Introducción, traducción (ed. Roman Teja; Madrid: Editorial Trotta, 2009) 49, 67. It is erroneous to think demons are seen as the cause only of mental disease, not physical, as does Canivet, Monachisme, 141. In proof, notice especially in the Life of Simeon the Younger that half the time, deformity, malfunction, or illness has each its own "demon," for example, at $\$ \$ 75$, 86, 200, 245, including leprosy (219); also Ven, Vie ancienne 56 n. 1. Beyond the Fertile Crescent among those most educated Greeks participating in the so-called Greek Enlightenment, a different idea of causation could be found; but even these outliers had disappeared by the fifth century of the modern era. See Ramsay MacMullen, "The Darkening of the West: A Note," in The Past as Present (ed. Giovanni Alberto Cecconi, Rita Lizzi Testa, and Arnaldo Marcone; Brepols: Turnhout, forthcoming); alternatively, in pre-published draft form, https://yale.academia.edu/RamsayMacMullen.

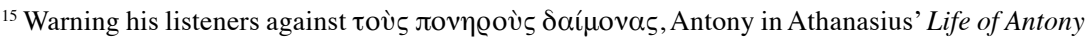
21.4 explains the ubiquity of demons, "in their throngs in the air around us, and not far from us, and of many kinds"; and again at 23.5 , "in the air everywhere."

${ }^{16}$ For prayers scratched on the walls of the memoria apostolorum in Rome, see Giovanni Battista de Rossi and Antonio Ferrua, Inscriptiones christianae urbis Romae septimo saeculo antiquiores, nova series V (Roma: Officina Libraria aem Cuggiani, 1971) nos. 12907-13906; Carlo Carletti, Epigrafia dei cristiani in occidente dal III al VII secolo (Bari: Edipuglia, 2008) 77, 266-268 (safe journey, one's chariot-choice in a race; compare Jerome's Vita Hilarianis 20, PL 23.37); representations of body-parts and other kinds of prayer in Johan Leemans, Wendy Mayer, Pauline Allen, and Boudewijn Dehandschutter, 'Let Us Die that Others May Live.' Greek Homilies on Christian Martyrs from Asia Minor, Palestine, and Syria (c. AD 350-AD 450) (London/ New York: Routledge, 2003) 12-13; on supplicant papyri, see Bell, Jews and Christians 102-9, and Rapp, "For next to God," 
to many others listed in the second Table, below. But at the core of life's concerns was ever, health (Table 1).

In summary as his biographer saw him, Theodore of Sykeon (d. 613) was "the blessed man, who overcame the Devil's wiles, put demons to flight, and cured the sick." It was the fulfillment of Jesus' instructions to his disciples. ${ }^{17}$ At greater length, a monastery-member at Amida in Mesopotamia recalled during the nights

the unceasing sighs, and copious tears, and crying and severe sobs, because everyone was looking at his fellow and everyone was emulating his neighbor and learning and acting, and was practicing and imitating and was eager to pass his fellow in the race of righteousness; so that many among them had the power of performing signs, and by faith were used to driving out fiends before our eyes. ${ }^{18}$

In the rivalry thus described, expanding on the words of another ascetic (Thalelaios quoted above at n. 10), a miraculous power of healing might be the reward, at least on this earth, gained by the devotee through his control of his natural impulses. It was the hope of those in turn who sought him out: that "he performed many miracles and healed many," or "thousands," or even "too many thousands to be counted." Such praises are common. In the Thebaid in Isidore's monastery every one of the monks, all "saints," were wonder-workers. ${ }^{19}$

Of the two supporting ideas, beyond salvation, that governed the ascetic's very essence-one, the social-ethical and the other, explanatory of afflictions - our surviving accounts inevitably assigned lesser urgency to the social-ethical; for recruits to the ascetic movement were overwhelmingly drawn from the agricultural

68-70; for supplicants asking for cures see the letter-collection among monks edited by Lucien Regnault, Philippe Lemaire, and Bernard Outtier, Barsanuphe et Jean de Gaza. Correspondance (Solesmes: Éditions de l'Abbaye de Solesmes, 1972) 82 No. 88 or 352 No. 534; and at martyrshrines, for example, the range of concerns in Basil, Homilia 19, In sanctos quadraginta martyres 8 (PG 31.524A); generals' concerns, in Enquête sur les moines d'Égypte (Historia monachorum in Aegypto) (trans. André-Jean Festugière; Paris: Cerf, 1964) 9 \$1.2 (this being volume 4.1 of the author's Les moines d'Orient 1961-1965, seven volumes in four): or Théodoret (ed. Canivet and Leroy-Molinghen) 13.15 (Macedonius).

${ }^{17}$ Sykeon, roughly 45 miles west of Ankara on the Roman road. Quoted, André-Jean Festugière, in Vie de Théodore (ed. Festugière) at 1: 2 \$2, comparing \$59 regarding a bishop of Dara/Anastasioupolis. On Jesus' instructions, Matt 10:8, to heal, see, for example, Canivet, Monachisme, 118.

${ }^{18}$ John of Ephesus, Lives, 35, in John of Ephesus, Lives of the Eastern Saints. Syriac Text Edited and Translated, (trans. Ernest Walter Brooks; 3 vols.; Paris: Brepols, 2003) II. 613. Compare rivalry in Historia monachorum in Aegypto, Prolog., 11; Festugière, Enquête, 8. Rivalrous asceticism was a common problem in coenobitic administration. Monks watched each other closely, admiring ascetic proofs that could be counted, see, for example, on genuflections, Theodoret, Hist. relig. 26.22, in Théodoret (ed. Canivet and Leroy-Molinghen) 2.204, or Besa's Life of Shenoute §1, or Historia monachorum in Aegypto 8.5 (ed. Festugière) 48; or the wonderful length of Daniel's hair, to the floor, Vita, 98 in Three Byzantine Saints: Contemporary Biographies Translated from the Greek (ed. and trans. Elizabeth Dawes and Norman H. Baynes; Oxford: Basil Blackwell, 1948) 69.

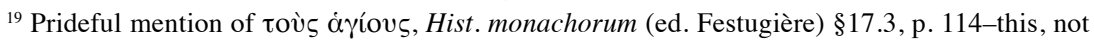
the only monastery where all or almost all members enjoyed "gifts." 
masses, without riches. Whether as solitaries or most often in groups and clusters, they could hardly seek the fulfillment of Jesus' injunction (Matt 19:21) to give all they had to the destitute. In fact they had nothing to give. The other supporting idea, however, addressed to demon-born afflictions, lay within every individual's power without need of material possessions. Indeed, the poorer one was, the better! Divine rewards attended one's caring for others who had even less of this world's goods than one's self. ${ }^{20}$

\section{Miracle-Working Powers}

A quotation, above, indicated keen rivalry in penitence among the monks of Amida. Ascetics certainly invented extreme regimens of self-denial, whether in prayer or physical suffering. But if they thus won thaumaturgic powers, how did the fact come to be recognized? Not by the say-so of some higher-up among the hierarchy. Only one answer seems imaginable, fitting naturally into the region at the time and supported by a prevailing familiarity with the notion of holy men, Christian or not. ${ }^{21}$ It is revealed when healing favor has been sought by a supplicant almost at random, as in the letter earlier quoted to the holy Paphnutius, and he responds, and a cure actually results; or some comforting prediction is sought, and gained, and the event in fact turns out happily. ${ }^{22}$ So, confirmation! The word spreads. Yet there was no predicting whose ascetic efforts would be rewarded, or when: as an instance, a certain Gabrielius, head of a church near Jerusalem, only toward the end of his long life "having become a worker of miracles." ${ }^{23}$ Before, he had been for decades an ascetic but not so empowered. Out of so many thousands, he at last counted as a "saint" and "blessed," earning a place in our sources.

Miracles had been wrought by the relics of martyrs from Polycarp in the second century on, through Euphemia's relics at Chalcedon or Crispina's in North Africa thereafter (but, to my knowledge, only one Christian woman was thought to receive thaumaturgic gifts during her lifetime). ${ }^{24}$ Cures were also wrought post-mortem

${ }^{20}$ Matt 19:21 quoted in John of Ephesus, Lives 21 (ed. Brooks) 283, apropos a certain Thomas. For miraculous power, the most common term is $\chi \alpha$ $\varrho \iota \sigma \mu \alpha$, as in 1 Cor 12:28, but is sometimes

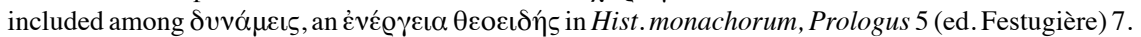

${ }^{21}$ Smith, Jesus the Magician, 86-91, for the first two centuries; for the next three, a few examples in Ramsay MacMullen, Christianity and Paganism, 196-97.

${ }^{22}$ The reward is known at a moment, as, for example, of Hypatius' Life 12.2, in Vida (ed. Teja) 47; of Benjamin in Hist. Laus. 12.1; of Maron in Theodoret, Hist. relig. 16.2 (ed. Canivet and LeroyMolinghen); of Euthymius, $\$ \$ 12-13$ in Cyril of Scythopolis: Lives (trans. Price) 18.

${ }^{23}$ In Cyril of Scythopolis: Lives (trans. Price) 52-53 §37; or similarly, Aphrodisius, §44, 144; again, Macarius in Palladius, see William Harmless, Desert Christians: An Introduction to the Literature of Early Monasticism (Oxford: Oxford University Press, 2004) 211.

${ }^{24}$ On Euphemia, see Raymond Janin, "La banlieue asiatique de Constantinople. Étude historique et topographique," Échos d'Orient 22 (1923) 335-86, at 382-85; on Crispina, see Ramsay MacMullen, The Second Church: Popular Christianity A.D. 200-400 (Atlanta: Society of Biblical Literature, 2009) 64-65. The sole exception I find is Piamoun in Palladius' chapter 31, being granted the power of prediction. Peter Brown, Authority and the Sacred: Aspects of the Christianization of the Roman 
by ascetics on the model of the martyrs, as, for example, by Simeon Stylites or by Hilarion and his biographer Epiphanius of Salamis, at their tombs. ${ }^{25}$ During their lifetime, such heroes had worked miracles from a distance by their prayers or by the touch of their clothing, perhaps, or drops of water or oil or both of these mixed together. ${ }^{26}$

With these particular persons we are among the "saints" as they are designated today; but in the centuries and eastern provinces of interest to me, formalities of titulature had not yet become established. The most devoted of God's devotees were more often called "the blessed," makarios, than "saint," hagios, and there are other terms applied evidently without rules and without any act of ennoblement by the hierarchy. ${ }^{27}$ Nevertheless, among the named ascetics, a substantial minority were sought out for some ecclesiastical rank, most of these only as priests, deacons, or heads of monasteries; and with promotion, still more ended up as bishops. The ladder of offices thus favored and gave an institutional structure to the ascetic movement. The fact should not obscure a more important reality, that, as the world saw it, asceticism itself was what counted, not ecclesiastical title. As a monk explained the departure of a certain brother, "he became a bishop, for he was a wonderworker." 28 True, one could rise partly by social position, partly by education; but the most honored path lay through a life lived as a devotee, philotheos, proven in

World (Cambridge: Cambridge University Press, 1995) 57, 61, is quite insistent that Christian women worked healing miracles "quite as much as men," but offers no support for the assertion.

25 "The ascetic is in many ways the successor of the martyr, ... [ [the martyr as] an ideal replaced by that of the ascetic, whose whole life was often regarded in terms of martyrdom," quoting Sebastian [P.] Brock, Syriac Perspectives on Late Antiquity (London: Variorum Reprints, 1984) 2; on miracles by Hilarion and Epiphanius, see below, n. 26.

${ }^{26}$ Healing by touching possessions, see Acts 19:12 as the model; Acta proconsularia S. Cypr. 4, Polycarp's linteamina et manualia; and so on in surviving sources, for example, a suppliant lying in the holy Barses' bed and so being healed, in Theodoret, Hist. eccl. 4.16.3. On ascetics' miracles post-mortem, see, for example, by Simeon Stylites' relics, in Three Byzantine Saints (ed. and trans. Dawes and Baynes) 41 §58; Euthymius' relics at work, in Cyril of Scythopolis: Lives (trans. Price) $57 \S 40$; the cures and exorcisms at the tomb of bishop Epiphanius of Salamis, in Soc., Hist. eccl. 7.27; or of Hilarion, in Soz., Hist. eccl. 4.10 and more fully in Jerome's biography. For ascetics sending liquid surrogates, see Doran, Lives of Simeon Stylites, 141-43 §§62-65, $151 \S 71$, etc., on hnana, a mix of oil and water; or the holy Z'ura using water alone, Brooks, John of Ephesus, 24-25.

${ }^{27}$ Hippolyte Delehaye, Sanctus. Essai sur le culte des saints dans l'antiquité (Brussels: Société des Bollandistes, 1927) 2, speaking of the "vague and ill-defined significance" of the word "saint"; 29, 32, hagioi are simply Christians, not an elite, excepting only martyrs (see, for example, 56) from Polycarp on; on Syriac usage, monks as "saints," see John of Ephesus, Lives (ed. Brooks) 159, 165; for the variety of descriptive terms, notice in the Life of Theodore of Sykeon (ed. Festugière) 2:12

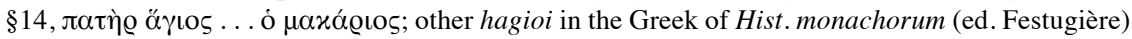
Vie de Théodore 9, at Prolog. \$13, also pp. 43, 46, 70, and 125; but rare in other sources, where also megas, thaumasios, philotheos, etc., describe the ascetic.

${ }^{28}$ I notice 19 bishops (five in John of Ephesus, counting John himself; two each in Socrates and Sozomen; the rest, scattered in my data-base). For the explanation of a promotion to episcopal rank, see Abba Isaac quoted in the Apophthegmata patrum (ed. Wortley) 205. 
daily practices and by the evidently resulting gift of powers. ${ }^{29}$ This primacy was recognized both by ecclesiastical officialdom and by the general public.

Perceptions bestowing celebrity were of two sorts, external and internal. As to the internal: within organized Christianity, one's fellow monks or bishops naturally observed one another's conduct of life, admired for reasons often explained at great length, edifying or eulogistic. They noted the holy man's humbleness and self-control. They gave prominence to theology, too, since the leadership rightly focused on such matters as orthodoxy and, by extension, on conversion. A good example is the choice of topics offered in letters attributed to the first great figure, Antony himself. ${ }^{30}$

As to external perceptions, they were Brown's target of interest declared on his opening page, as they are my choice, too-a focus on the "position in society" or place of the holy man. Ascetics would most naturally become known for their puzzling behavior; much more, however, through the notion that this might empower them to help with one's own afflictions. Appeal could be made to Jesus' message, to give to those in need, raise the cripple from his bed, heal the afflicted. As an illustration of the response, perhaps the earliest known, there is an entry in the calendar of Alexandria: "In this year, too, Anthony, the great leader, came to Alexandria and, though he remained there only two days, showed himself wonderful in many ways and healed many." 31

The healings were true miracles, beyond the powers of ordinary mortals. Embarrassment about them is common in modern times, for example, in Cardinal Newman's dismissal of a "stupid credulity" among the believers of those ancient times; and sometimes indeed the inventiveness of the ascetic community and the gullibility of visitors will surprise us. ${ }^{32}$ Miracles thus might need a special

\footnotetext{
${ }^{29}$ The particular notice earned by wonder-working is indirectly evident in the flow of biographies, from a subject's thaumata to the wish expressed that he accept a priesthood or other office; but sometimes directly expressed, as, for example, in a monk Moses' promotion to a see "thanks to his apostolic teachings and his miracles" (Theodoret, Hist. eccl. 4.23 .5 [trans. Canivet] 2.293).

${ }^{30}$ Samuel Rubenson, The Letters of St. Antony: Monasticism and the Making of a Saint (Minneapolis: Fortress, 1995). Though sometimes described cautiously as "attributed," Antony's letters have won general acceptance more recently, seen for example in Peter Gemeinhardt, Antonius, der erste Mönch. Leben, Lehre, Legende (München: Beck, 2013) 19. On the inner life of early ascetics, see David Brakke's Athanasius and the Politics of Asceticism (Oxford: Clarendon, 1995), for example, 204-13, 253-54, and Nathan Kwok-kit Ng, The Spirituality of Athanasius (Bern/ Berlin: P. Lang, 2001), with Rousseau, Goehring, Finn, and other cited above. It has not been noticed that attestation of Antony's letters reaches back no further than the $330 \mathrm{~s}$, that is, not into Antony's prior life as a solitary where they are hard to imagine.

${ }^{31}$ The Festal Epistles of Saint Athanasius, translated from the Syriac (Anon. trans. [Henry Burgess]; Oxford: J. H. Parker, 1854) xviii; Athanasius, Vita Antonii 69.2-3, "everyone ran together to see Antony . . . for the Lord through him cleansed many demons and healed persons deranged" (in the 330's). Compare the holy Julian's entrance to Antioch, Theodoret, Hist. relig. 2.18, or Theodore's entrance to Nicomedia, Life of Theodore of Sykeon $\$ 158$ in Vie de Théodore (ed. Festugière) 137.

${ }^{32}$ Much of the evidence for this creativity is found in the very detailed visions reported by holy men; but for a good example of gullibility see the Historia monachorum in Aegypto, 9.2-4.
} 
interpretation - Newman may be quoted to that end - but they remain still a reality for many, affirmed by anyone like myself who has watched a new family member at baptism insufflated to protect the child against the evil Spirits that permeate our world. It is realities as understood by the observer that dictate thoughts and actions; and the thoughts and actions in the past are what historians must work with. ${ }^{33}$

Granted, there remain some realities of doubt. Even in those ancient times as now there were sceptics about signs and wonders, thaumata; but they were few and far between, outnumbered by the most reliable eye-witnesses. ${ }^{34}$ Consider the centuries of my special interest, ending in the run-up from the long-drawn-out Greek enlightenment, to the Dark Ages. In the interval between these two, obviously a very consequential change took place, the tracing of which may be left to a separate study. It was in any case characterized by "irrationalism" and "credulousness," as so many scholars have agreed.$^{35}$ Beyond that, in the second place, it was a period of accelerated Christianizing. And in the third place, it was a period of destruction of pagan temples, beginning in 326 with that of Asclepius at Aigeae, to which, as to others like it all over the empire, sufferers had been accustomed to resort for healing of mind and body alike. ${ }^{36}$ Bearing in mind these three historical facts, is it not natural that so major a phenomenon as the ascetic movement might originate in their concatenation? Within it - a perfect storm - might one not expect to find some type like the holy man emerging? In fact, the various peoples native to the

\footnotetext{
${ }^{33}$ John Henry Cardinal Newman has been sometimes quoted, in his Historical Sketches (London: Longman's Green, 1899) 315-17, confronting the "stupid credulity" of Theodoret and seeing in it only an instrument of a good outcome; yet "scholarly embarrassment" persists, see, for example, on "ascetic experiences," Georgia Frank, The Memory of the Eyes: Pilgrims to Living Saints in Christian Late Antiquity (Berkeley: University of California Press, 2000) 45, with Derwas Chitty among others pointing out the problem "even among generous interpreters," or Kate Cooper, "Reti di famiglia, reti di evangelizzazione: la famiglia tra paganismo e cristianesimo nella Passio Sebastiani," Pagans and Christians in the Roman Empire: The Breaking of a Dialogue $\left(I V^{\text {th }}-V I^{\text {th }}\right.$ Century A. D.). Proceedings of the International Conference at the Monastery of Bose (October 2008 (ed. Peter Brown and Rita Lizzi Testa; Vienna: Lit, 2011) 245-69, at 246, noting in a certain scholar "the embarrassment of our modern selves confronting the high style of miracle-working present in ancient sources." Escolan, Monachisme, 1, rightly warns against the tendency of "the modern mind" simply to block out those "disturbing" aspects of ancient Christian belief that seem "extreme" rather than recognizing that "the monastic world had its own logic." As to insufflation against evil spirits by the Holy Spirit, see An Episcopal Dictionary of the Church (ed. Don S. Armentrout and Robert Boak Slocum; New York: Church Publishing, 2000) 266. For those historians who follow trends in methodology, the question of miracles well illustrates the etic-emic debates of the last generation, see Michael C. Alexander, "Roman Amoralism Reconsidered" (1990), http:// romanamoralismreconsidered.com 97-99.

${ }^{34}$ On sceptics, see MacMullen, "The Darkening," at nn. 14-16; sceptics in, for example, Philostratus, Vita Apollonii 7.38-39, or Hist. monachorum in Aegypto 13.12; personal witness, for example, George of Sykeon in the Life of Theodore §126, in Vie de Théodore (ed. Festugière) 2:193.

${ }^{35}$ MacMullen, "Darkening," at nn. 7, 16, 24.

${ }^{36}$ Aigeae, see Eusebius, Vita Constantini 3.56. By the close of the third century there were more than 150 Asclepius temples in the Greek world, reflecting the primacy of healing-aid, cf. Dunand, "Syncrétismes et forms de la vie," 2,3: 357.
} 
Fertile Crescent and Near East had been for many centuries open to the notion of a "divine man," gaining more than mortal powers.

This openness appears in the papyrus letter which I quote once more, written by a person otherwise unknown to a certain Paphnutius, a local holy man equally obscure, seeking health aid; for it was common knowledge (the letter says) that people so devoted as he to a higher Power might share it with others. Such was the belief that occasioned the letter; here was its motivation; and in motivation we have the bedrock of historical interpretation. Further, we have Gregory of Nyssa writing about a wonder-worker famous locally in times long past. The bishop concludes with a rebuke to any doubters, thus acknowledging the difference in beliefs about miracles that divided people like himself from the masses. Together, the two documents are perhaps enough to illustrate the broad base of belief that supported the holy-man type. ${ }^{37}$

Without now attempting any formal treatment of the matter, but only to suggest how the transition to post-Constantinian times might be understood, I turn first to Ludwig Bieler's study titled " $\Theta E I O \Sigma$ ANHP," as the holy man was hailed by followers. Here the evidence is gathered very fully, drawing on both Greek and Jewish texts from Homer to the prophets, to the historical Jesus and beyond, with parallels found also in saints' biographies. In reading the life-story of such a person, details about his conception, parentage, birth, naming and re-naming can be seen to be touched with some portent or prodigy. ${ }^{38}$ The sequel to Bieler is Morton Smith's equally full and careful study of New Testament times referred to above (n. 14), in which he makes good use of evidence in papyri and especially clarifies perceptions of wonder-workers among the population in general both in Palestine and Egypt.

Egypt by itself alone, through its papyri but also through other material evidence for religious beliefs, affords unique depths of detail. In a study a decade later than Smith's, Françoise Dunand (1990) could thus discern and make clear how central in religious life were concerns for health; and this was all the more sharply the case as the population's familiar deities and temples were dishonored or destroyed. It accounted for those appeals to the province's various immemorial deities, whether supplicants were "pagans" (in her scare-quotation marks) or Christians. The latter

${ }^{37}$ I try to make clear to myself the need in interpretations to look for motivation, in Why Do We Do What We Do? (De Gruyter Open Access, 2014) available gratis, as well as hardback. As to the papyrus letter, see above, n. 8; and in the Nyssa bishop's account of Gregory the Thaumaturge, with due emphasis on healing ( $\$ 76-79,96-99)$, notice how it ends $(\$ 100)$ : still more miracles known to oral memory are withheld by his eulogist only "to spare them an unbelieving reception."

${ }^{38}$ Ludwig Bieler, $\Theta E I O \Sigma$ ANHP. Das Bild des 'göttlichen Menschen' in Spätantike und früh Christentum (Darmstadt: Wissenschaftliche Buchgesellschaft, 1967) 3, 25, 31-33, 41, indicates points in Jesus' and Paul's stories that find parallels in non-Christian examples. On the term for the

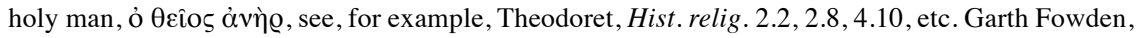
"The Pagan Holy Man in Late Antique Society," JHS 102 (1982) 33-59, in a very rich exposition of this human type from ca. 275 through the sixth century, deals (as he emphasizes, 48-51) with a being of a highly privileged class, who in this and other respects differs from the earlier, less intellectual, holy man that more closely resembles the Christian. 
response, the Christian, with more than probative texts, both Greek and Coptic, can be used to show how "the practices [of the holy man] are quite like those employed in "pagan' healing shrines." "Was that a sign of "Christianizing," or of "conversion," or "syncretism," or "semi-Christianity"? A generation later, David Frankfurter in a wide-ranging volume treated these lexical/theoretical questions, and others more briefly discussed by Dunand; he, too, discovered a gradual melding of accepted practices from the traditional into that of the hierarchically approved supernatural powers - the Christian - granted to the holy man by God. ${ }^{40}$

\section{Powers Profiled in Tabular Form}

In the three Tables below, the first item (1) underscores what distinguished and explained the salience of wonder-workers among all holy men. They healed. Even when they had been torn from their monasteries by a certain persecutor in the $360 \mathrm{~s}$ and driven into the wastelands, there they could be found "going about their usual practices, praying, healing diseases, driving out demons." 41 It was this that got them talked about and remembered in biographies and in the stories told to religious tourists; this, that enucleated their claim on reverence and gratitude when their lifestories were summed up; this, in single mentions that tell us not of individuals but of whole families, whole groups that are healed, villages or crowds, or "numbers too great to be counted." On that very account they cannot be represented in any calculations. My own choice to count item (1) in the individual profiles as one single thing is thus hyper-conservative.

Within that healing power, as the next item (2) in my first Table indicates, it was exorcism that stood out. Nothing was so spectacular or so lovingly reported as the conversation between demons resident in the possessed and the saint who drove them out. Adding five more items (3-7), to finish with health, brings that wonderworking area or focus to almost double the number (items 9-19) of miraclementions bearing on other needs. All that should be pointed out regarding those other needs is that we are dealing with a largely agricultural population for whom draft animals were a major asset (item 8) and pest-control, meteorology, and hydrology (items 14, 17, and 18) were especially important kinds of knowledge.

\footnotetext{
${ }^{39}$ Françoise Dunand, "Miracles et guérisons en Égypte tardive," Mélanges Étienne Bernand (ed. Nicole Fick and Jean-Claude Carrière; Paris: Annales Littéraires de 1'Université de Besançon, 1991) 235-50, at 249, quoted, in an essay compressing a great deal into a short span. She builds on the foundational work of Delehaye, Bidez, Chabot, Festugière, and other French scholars rather neglected in Anglophone scholarship.

${ }^{40}$ See David Frankfurter, Christianizing Egypt: Syncretism and Local Worlds in Late Antiquity (Princeton: Princeton University Press, 2018), at various points, richly documented. For an account of his and Dunand's subject matter as it is found in more than the one province of Egypt, with generally compatible conclusions, see MacMullen, Christianity and Paganism, chapters 3-5.

${ }^{41}$ Socrates, Hist. eccl. 4.24 (PG 67.4.24A).
} 
Table 1. Miracles Health-related (Occurrences/Mentions)

\begin{tabular}{|l|l|l|}
\hline 1 & Healings often, or of many individuals or in crowds & 108 \\
\hline 2 & Mental health/exorcisms & 112 \\
\hline 3 & Cures, sometimes exorcizing, for physical ills & 142 \\
\hline 4 & Specifically infertility & 15 \\
\hline 5 & Specifically blindness/eye-problems & 21 \\
\hline 6 & Specifically speech-loss/mutism & 14 \\
\hline 7 & The dead raised & 8 \\
\hline 8 & Veterinary & 15 \\
\hline
\end{tabular}

Table 2. Miracles Unrelated to Health

\begin{tabular}{|l|l|l|}
\hline 9 & Many unspecified/various miracles & 28 \\
\hline 10 & Predictions/prophetic & 46 \\
\hline 11 & Second sight/mind-reading/telesthesia & 45 \\
\hline 12 & Crosses streams dry-shod & 7 \\
\hline 13 & Controls harmful animals & 44 \\
\hline 14 & Controls insects/locusts & 7 \\
\hline 15 & Or in other ways secures good harvests & 3 \\
\hline 16 & Delays sunset; controls fire, boiling & 6 \\
\hline 17 & Control over weather, storms, hail & 13 \\
\hline 18 & Control over water-flow, rain & 27 \\
\hline 19 & Control over terrain, rocks, etc. & 7 \\
\hline
\end{tabular}

Table 3. Social Ills Addressed

\begin{tabular}{|l|l|l|}
\hline 20 & Feeds many with little food, few loaves & 18 \\
\hline 21 & Champions/succors the needy & 42 \\
\hline 22 & Bad people controlled/immobilized/punished & 68 \\
\hline 23 & Reconciles groups to each other or individuals & 18 \\
\hline 24 & Reconciles individuals & 15 \\
\hline
\end{tabular}


In the third Table (items 20-24) we turn from ascetics' interaction with nature to their interaction with the secular world around them. Here, the region's immemorial social ethic showed its force: as a minimum, against the starving of the poor. Here, ascetics as individuals could certainly help; though denied the worldly means, they could work miracles (20). ${ }^{42}$ Monks too, ascetic in their own way but without need of special powers, indeed much more effectively, could show compassion for the destitute, reaching out and sharing their common surplus. Increasingly their own resources included gifts, among them, gigantic ones from that multimillionaire Melania. Increasingly they gained a place for themselves, locally, in their institutional form; the heads of houses, figures of authority, were asked to intervene around them in conflicts between the poor and their oppressors. ${ }^{43}$ They won much praise for this. Even more often and on a larger scale, bishops could act. By the lifetime of Antony "of the Desert" and the converted Constantine, they had had many generations to solidify their power, to acquire property and the rights to land-rents; they had gained social position, too, and open-handed friends. Now, in their duty as they perceived it to succor the poor, they could at last deal effectively with the secular world and its realities on its own terms, realities so often involving money.

${ }^{42}$ In general, and often noticed, monks strive to imitate Jesus, as in Matt 14:13-22, 15:32-38, and elsewhere, feeding crowds; compare the life of Simeon the Scribe in Brooks, Lives of Saint Simeon, $\$ 34$ 615-16, where a thousand are fed with a few loaves; similarly, the Life of Hypatius $\$ 20.1-2$, in Vida (ed. Teja), 52-53; Cyriacus in Cyril of Scythopolis: Lives (trans. Price), \$20 257; or the Life of Alexander Akoimetos §45, in Wandering, Begging Monks: Spiritual Authority and the Promotion of Monasticism in Late Antiquity (ed. Daniel Caner; Berkeley: University of California Press, 2002) 261.

${ }^{43}$ Monasteries and churches commonly had guest-houses or hostelries and, by Basil's day and John Chrysostom's, these might be turned into homeless shelters for "beggars" and "the aged," as the special names for them show. John Cassian (d. 435) explains the provision by Egyptian monks: a tithe of their annual funds. For a general view, see Otto Hiltbrunner's richly documented article

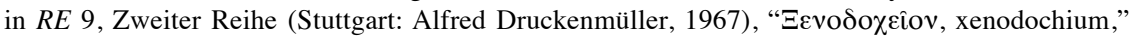
esp. 1490-1499. Cod. Theod. 16.2.42-43 (416) is useful. To Hiltbrunner I can add only reference to Thalassios who "collected many who were blind and had to be beggars, and he made a refuge for them here and there and everywhere, and his visitors fed them," in Theodoret, Hist. relig. Chap. 22.7, in Théodoret (ed. Canivet and Leroy-Molinghen), 2:133; Mary, for whom "there could not be any sick poor man among those lying in the streets who escaped her so she did not visit him either twice or once a day," in John of Ephesus, Lives §XII (ed. Brooks), 166; similarly the abbot Alexander Akoimetos (d. 430), in the Life 33, who "nourished the poor like a father and taught the rich to do good deeds," see Caner, Wandering, Begging Monks, 269; a little later, the famous Shenoute (d. 460), known to be friends even with the local governor, see Ariel G. Lopez, Shenoute of Atripe and the Uses of Poverty: Rural Patronages, Religious Conflict, and Monasticism in Late Antique Egypt (Berkeley: University of California Press, 2013) 30, 131-33; Blum, Rabbula, 78; and Schachner, "Archeology of the Stylite," 363. On Melania the Younger, dispensing 35,000 gold coins to eastern monasteries, see Palladius, Lausiac History, 61.3-4 (equivalent to the average annual earnings of more than 50,000 men); modest donations to a monastery, for example, in the Life of Simeon the Younger 49, Ven, La vie 55; and a grand gift to an individual ascetic, for distribution, in Émile Amélineau, Histoire des monastères de la Basse Égypte. Vies des saints Paule, Antoine, Macaire, Maxime et Domèce Jean le Nain, etc. Texte copte et traduction (Paris: Leroux, 1894) 104. 
As an illustration of power, though extreme, we have the largest sum of money ever recorded in the hands of a single person other than the ruler himself during the Roman Empire's many centuries: the cash that Cyril bishop of Alexandria could command in 433 when he needed it. His contemporary in the see of Edessa could count annually on an income above two million of today's dollars. ${ }^{44}$ Figures like these, however unusual, suggest the gulf that divided Haves from Have-Nots, in an economy in which much was wrung from the many by the few. It was this that demanded "social justice" as it is bluntly termed by Rabbula's modern biographerthis justice, one of the governing ideas underlying the ascetic movement. ${ }^{45}$

\section{The Haves and Have-Nots}

In action can be seen three players. Most obvious was the emperor through his soldiers at the interface with his subjects, enforcing his will above all in tax collection; also, landowners (including bishops) who might as such be the owners of entire villages, collecting rents or crop-shares; and caught between the two big figures, other lesser ones: small farmers and landless peasantry -in all, a power structure about which the sources for the eastern empire are fortunately not too bad. ${ }^{46}$ The overall structure very often allowed the intervention just reviewed, by hermits, monks, and bishops. Illustrating the role of these latter, passages of description that are hostile toward too-greedy landowners duly appear in the sermons of Basil and John Chrysostom. They were presumably inspired by the real stories they heard from farmers all around, that is, in (modern) Turkey and Syria.

Besides the two sermonizers, a third voice around 390 was raised against the greed of the powerful. Libanius spoke out against the commander of troops billeted at Antioch who, for a price, promised to shield the local peasantry against any rentcollection by landowners. The Greek in Libanius' speech has been misread to turn the situation upside-down: in fact, the "protection" offered to the peasantry was a cruel bargain, a shake-down as Libanius saw it and as the villagers did, too; but they were caught in the middle. ${ }^{47}$

${ }^{44}$ On Cyril's payment for the recovery of his see, see Ramsay MacMullen, Corruption and the Decline of Rome (New Haven/ London: Yale University Press, 1988) 165-66; on Edessa, see Blum, Rabbula, 73 with n. 70, explaining that the daric in the annual income of 7,000 is a guinea (meaning the British gold coin, from which I offer my equivalent for today, though its buying power is incalculable). The bishop's source (74) was most likely gifts.

45 "Die soziale Gerechtigkeit" is what Blum, Rabbula, 73, sees as required of, and vigorously observed by, the bishop, along with Armenfürsorge and Krankenpflege.

${ }^{46}$ This structure is the subject of MacMullen, Corruption, where Basil and John Chrysostom are quoted (85); notice is taken of the patron system and its general prevalence (169); also sources on extortion by the military (150-52, 158-62); and Libanius' Or. 47 on patron roles $(159,169)$, where Alfred Francis Norman, ed., is useful, in his Libanius. Selected Works (2 vols.; Cambridge/ London: Harvard University Press, 1969-77) 2:494-99. He dates the oration around 390. The problem of the orator's irony is indicated by the editor with "scare quotes" (494, "protectors") and is also

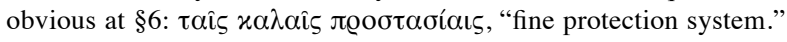

${ }^{47}$ See above, n. 46; below, nn. 48, 50, 59. 
In such a situation, the Have-nots might have appealed to a bishop, if known for his sense of justice: to Theodore of Sykeon, for example. On a visit to one of the villages belonging to the cathedral, he ran into both its avaricious "protector" and the villagers' complaints against the man, who, by a miracle, within a day, presented himself to Theodore to report a vision he had had. An angelic epiphany had warned him he'd better behave; so now he begged the bishop's forgiveness and promised reform. ${ }^{48}$

Another anecdote serves to show how the realities worked: this one, concerning young Abraham of a good family. Like John Chrysostom or Rabbula, not to mention Jerome and many others less known in their early years, he went off by himself for a test of asceticism. ${ }^{49}$ In the nearby village were nothing but non- believers. He determined to convert them; and to gain an entrée against their hostility he got his friends' help in buying a stock of goods for sale and rented rooms as a businessman. By chance, harsh tax collectors were at the moment besieging the villagers, who begged Abraham to be their "protector." From his friends he got a hundred gold coins to meet the collectors' demands, a huge sum. He was rewarded by the village with its conversion. He took up residence. Next came the building of a church, his appointment as its priest, and a few years later, his ordination as bishop of Carrhae. There he became famous for his justice in disputes submitted to his judgement. ${ }^{50}$

And last, the example of Simeon Stylites the Elder. Like other ascetics he was sometimes asked in his wisdom to straighten out relations on a quite personal level. ${ }^{51}$ Our sources, however, naturally have much more to say about larger concerns. He responded once to a whole crowd of Antioch's dyers who sought his aid, these, the most wretched of the laboring class, the most to be pitied; but in such matters,

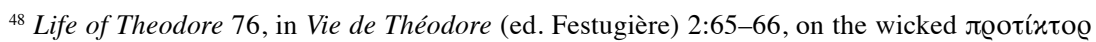
(sic). The term (despite Festugière's uncertainty, 2:186) is as he says at 2:201 (§45) and 2:220 (\$76), the equivalent of Village or Town Headman, in whom a bishop would naturally see a deputy. It could also designate an imperial Guardsman.

${ }^{49}$ In addition to big names that experimented with asceticism, there are many others less known who moved into a church career, for example, John the Hesychiast in Cyril of Scythopolis: Lives (trans. Price), 220, or Abraham in Theodoret, Hist. relig. 17.2-3, in Théodoret (ed. Canivet and Leroy-Molinghen) 2:35-36.

${ }^{50}$ On the common practice of a town or village choosing a protector or patronus in the first to the third centuries, in the East, see Louis Harmand, Le patronat sur les collectivités publiques des origines au Bas-Empire (Paris: Presses Universitaires, 1957) 314-15. For the Abraham example, see Theodoret, Hist. relig. 17.3-8, the site being a nameless village on the upper Orontes. Abraham turns to $\gamma v \omega \varrho$ í $\mu$ ov $\varsigma$ in Emesa for financing ( $\$ 3-$ a single gold coin was a year's pay for two soldiers)

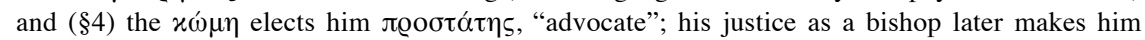
famous (\$8). On the familiar position of advocate in the region, see such intermediaries as Rabbi Abbahu, in MacMullen, Corruption, 206; also Grey, Constructing Communities, 106, instancing Rabbi Eliezer as parnas.

${ }^{51}$ On private counseling by ascetics, see, for example, the Syriac Life of Simeon 26, in Lives (ed. Doran), 116; for other illustrations, see Antony, Life, 14; Theodore of Sykeon, Life, 145; or Aphraates and Abraham in Theodoret, Hist. relig. 13.13 and 17.8; especially Barsanuphius in Regnault, Lemaire, and Outtier, Barsanuphe, at various points offering in-house advice to monks. 
ascetics were often active. ${ }^{52}$ Lest the holy man's interventions be treated lightly, or himself insulted, there were the tales of what might happen to the guilty (remarkably prominent, see the number of mentions, item 22). A bishop, too, if he were seen as philotheos was sure to be protected by the same stories. ${ }^{53}$

Simeon was, however, unique in one essential respect. Where others had fled the world, giving themselves to their penitential routines and narrow cells and hiding their sufferings as best they could in obedience to Jesus' teaching (Matt 6:1, 5-6), he advertised himself with extraordinary ambition. He chose for his eventual residence a hilltop within a day's walk of Aleppo, serving the population from all around. Theodoret in the Life $(\S 11)$ describes how, over the years there, the privations he inflicted on himself were of a sort to excite absolute amazement, carrying his name to the furthest parts of the known world and attracting a corresponding press of petitioners for healing. There to avoid their crowding, a platform was first raised for him on a nine-foot pillar and subsequently, thrice, to a height above fifty feet; there, ever greater crowds daily attended him, needing various services and facilities. At his death, his fame found prompt expression in built stone, forming an enormous center for religious tourism, while his relics were entombed at Constantinople, center of everything. In its suburbs his successor Daniel, already much in the news for his miracles of healing, erected his own more modest pillar, and later, Daniel's successor and imitator in turn, Simeon the Younger. ${ }^{54}$ This latter (b. 521) put up

${ }^{52} \mathrm{He}$ defends the poor against harassment, see the Syriac Life of Simeon $\$ 34$ in Lives (ed. Doran), 124-25. On the Antioch deputation, the dyers' tax rise of $300 \%$ being imposed by a cruel magistrate, see the Life 56, in Lives (ed. Doran), 135-36. On interventions to defend the weak, see also Alexander Akoimetos in Antioch, Life §38-39, in Caner, Wandering, Begging Monks, 272-73; in the eulogy of Gregory the Wonderworker $\$ 47$, Gregory of Nyssa describes how by that bishop "the powerful were taught to be kindly, $\phi \iota \lambda \alpha v \theta \varrho \omega \pi \varepsilon v \varepsilon \sigma \theta \alpha$, to those who were their subjects," in Pierre Maraval, Grégoire de Nysse: Éloge de Grégoire le Thaumaturge. Éloge de Basil (Paris: Cerf, 2014) 160-61; similarly, the administration of Jacobus, in Theodoret, Hist. relig. 1§7; likewise of Hypatius in Constantinople, Life 6.7-8, in Vida (ed. Teja), 42; Habib in John of Ephesus' Lives chap. 1 (ed. Brooks), 8; or the bishop of Chios, Kashish, chap. 51 (ed. Brooks), 159.

${ }^{53}$ Punishments, Life of Simeon 39 and 56 (ed. Doran), 124-25 and 135-36; compare Daniel's Life 75, in Three Byzantine Saints (ed. and trans. Dawes and Baynes), 53. For passages showing the alarming misfortunes that befell persons hostile to a bishop, Basil, see Ramsay MacMullen, "Response," in Protocol of the Thirty-fifth Colloquy, Center for Hermeneutical Studies: The Role of the Christian Bishop in Ancient Society (ed. Henry Chadwick, Edward C. Hobbs, and Wilhelm Wuellner; Berkeley: Center for Hermeneutical Studies, 1980) 25-29, at 29.

${ }^{54}$ Qalat-Siman from Aleppo is about a 350-foot climb over a 19-mile distance. On the pillar's height, see the Life 12, eventually 36 cubits. The last twenty-foot section would have weighed 12-15 tons, involving an immense expense in transport, draft animals, scaffolding, cranes, and labor - an effort in which tradition shows no interest. On his rejection by the monastic community everywhere, and his eulogist's uneasiness, see Canivet, Monachisme 110, 112-18. As for the sanctuary around his tomb, see Schachner, "Archeology of the Stylite," 366, 370, facilities for "the thrill of tourism" offering "the allure of "bizarrely sacred' places." On the armed force needed to safeguard the removal of his relics first to Antioch from the outraged Syrians, see Marcell Restle, "Kalaat Seman," Reallexikon zur byzantinischen Kunst, (eds. Klaus Wessel and Marcell Restle; Stuttgart: Anton Hiersemann, 1978) 3:856-57; and on Daniel at Constantinople, Life 26, in Three Byzantine Saints (ed. Dawes and Baynes), 22. On Daniel's cures wrought on the city's bishop, on 
his pillar near Antioch. Thereafter the stylite series tailed off; indeed the ascetic as a type had already begun to yield pride of place to the holy martyr. ${ }^{55}$

My various illustrations, focusing for a moment on Libanius, then on Theodore of Sykeon, Abraham, and Simeon the Elder, are meant to make more vivid the quantifications offered in my third Table. They do show moral authority invoked to help with more or less ordinary interpersonal problems in the spirit of the seventh beatitude: blessed are the peacemakers (Matt 5:9); but this is rarely mentioned. It wasn't miraculous. More often it is some serious affair where conflict involves the Haves against the Have-nots, the force of the prevailing social ethic is applied and can be felt, and it is the ordained leaders of the church who emerge as the heroes.

Of course this must be so; for bishops, even abbots, had clout and connections; they could call on financial support for solutions. Shenoute may serve in illustration, in the Life (81-82) by his biographer Besa. Institutional advocates were bound to outweigh the amateur-for so we may describe the holy man. Grotesque in his look and costume, beneath humility itself in his speech and address, what could he do? True, as his followers were prompt to remind visitors and their own readers, divine power abetted him; the fact emerges in the record (item 22), as was noted; if he was treated with disrespect or defiance, divine punishment might fall on the offender, sometimes quite miraculously, sometimes without need of any curse or invocation. It simply happened. Yet when these matters profiled in the third Table are given their full weight, the popular perception of ascetics is not much affected: they were above all miracle-workers, not social workers.

They were seen as thaumaturges, semi-divine. That they were not to be crossed was simply a part of who they were, in whatever way they chose to act; it was a part of their authority; but it was known that different individuals by their devotion, their theophilia, had been granted different powers. Which powers were called on depended on who asked, with what needs. Holy men responded; they didn't initiate. Their place in the world, aside from the matter of their own salvation, was marketdriven. There was thus much demand from farming folk, as was pointed out; there was a much, much greater demand for the treatment of everyone's physical and mental health problems. Whatever people had once prayed for in pre-Christian times, Antony or Theodore might now know how to obtain. So ascetics had their day, they had their fame, enthusiastically inflated by their followers. Access to the blessings they had earned for others was, however, more and more often sought from still mightier saints in martyrs' tombs.

a former consul, the emperor's major domo, and the empress herself, infertile, see the saint's Life $20,28-29,31,38$, and 40.

${ }^{55}$ On the series of the pillar saints, Schachner, "Archaelogy," 332, lists the ten attested textually. The list, after the first three, counts one of the sixth century on the Armenian border, and the rest, still later. 


\section{Ascetics Are Mediators as Peter Brown Sees Them}

To conclude, now, I return to my starting point, the 1971 article on the holy man, where I reviewed its two foundational assumptions critically. A third point of almost equal importance to Brown's essay was correctly summed up twenty years later by Robert Doran, noting that ". . . [a]midst all the discrepancies in detail, one can observe in the Life [of the first stylite] features of that daily work-load of mediation that Peter Brown pointed to so brilliantly - 'what men expected of the holy man coincides with what they sought in the rural patron.'" Brown's proposition was accepted almost immediately and almost without challenge, as appears in a gigantic footnote, above (n. 6). ${ }^{56}$ It was treated by him mostly in the context of the eastern provinces and within them, in Syria. In the past, he asked, how had the rise of this figure been explained? Answer had been sought in the figure of the "divine man," the $\Theta E I O \Sigma$ ANHP, recalled above. Brown's article, however, rejects all of this, perhaps as unedifying. ${ }^{57}$ What remains is the central notion of the holy man as "mediator" - a term that is indeed key, as appears in Doran's understanding of it (quoted above), in the company of many other scholars to the present day. ${ }^{58}$

Here, however, the attendant problems seem quite intractable; for, at the start, as is well known, the Have-nots in their need to confront the too-greedy, continued in late antiquity to seek defenders from among the Haves, not in some new world, but in the long familiar ways. ${ }^{59}$ Help from someone wealthy, thus influential, thus

${ }^{56}$ Quoted, Lives (ed. Doran), 18; confirmed by mentions in Brown's article insistently picturing the holy man as a "mediator" $(89,90,92)$, an "arbiter" (93), and "hinge-man" (86, three times). On the prevalence of Brown's image of the holy man in modern scholarship, notice Drijvers, Hellenistic, 31 , "the holy men are always ready to participate in the social life of the common people and the social elite," etc.; or Carol Straw and Richard Lim, "Introduction," The Past Before Us: The Challenge of Historiographies of Late Antiquity (eds. Carole Straw and Richard Lim; Turnhout: Brepols, 2004) 11-18, at 12, on "the holy man as a political and social mediator, as well as a social catalyst," in Brown's "seminal” work; Grey, Constructing Communities, 131, on holy men "often enmeshed in local power structures and broader networks of communication and influence," where their "isolation" is only an "illusion." For the sole challenge, see the Dean of early Church studies, Henry Chadwick, saying about interpretations of the early saints, "we go in search of trendy nonreligious explanations of the social needs that created them," in Chadwick, "Pachomios and the Idea of Sanctity," in The Byzantine Saint: University of Birmingham Fourteenth Spring Symposium of Byzantine Studies (ed. Sergei Hackel; London: Fellowship of St. Alban and St. Sergius, 1981) 12. There can be no doubt what Chadwick was referring to. Against the article's ambitions, further, Warren Treadgold, "Taking Sources on Their Own Terms and Ours: Peter Brown's Late Antiquity," Antiquité tardive 2 (1994) 153-59, at 156, remarked, with justice, "it seems improbable that as much as $5 \%$ of the population of the Later Roman Empire ever saw a holy man."

${ }^{57}$ The title of Bieler's book is recalled by Brown to show it had been consulted, even though not cited. Bieler did indeed point out non-Christian analogies to the familiar Christian narrative but only thaumaturgical parallels are cited by Brown, to be dismissed as superficial.

${ }^{58}$ Doran quoted, above, n. 56. Frankfurter, Christianizing Egypt, 5, can accept Brown's picture of the "mediator," hesitatingly, but (chapter 3) only by taking "mediator" to mean anyone in any contact with any group different from his own. This is certainly not Brown's picture.

${ }^{59}$ On the routines of patronage, see above at $\mathrm{nn}$. 46-48. While Brown makes use of Louis Harmand's study of Libanius' $47^{\text {th }}$ oration, he neglects Harmand's much grander and more useful 
powerful, continued to be the resort of the Have-nots whether the offensive greed was the tax collectors', corruptly, or that of some big landowner acting through his agents. From the mid-third century, increasing involvement of soldiers in government brought them further forward as a third member to the two-party scene of rich and poor; and after the improvement in the position of the Church post-Constantine, as was emphasized above, a fourth party appears, in the form of local priests, abbots, and bishops, with their various degrees of clout and control of wealth. ${ }^{60}$ But with these ecclesiastical officials Brown is not concerned.

Central to his argument, instead, and in support of a new, mediating figure emerging from the "religious revolution," are two texts. Both were recalled on earlier pages, above. The first was Libanius' oration in defense of civilian patrons against encroachment by the military. In "Rise and Function," this was quite misunderstood. ${ }^{61}$ The second text was, if not misread, at least used to prove too much. It involved young Abraham, as described above, abandoning his initiation into a hermit's life in order to help a nearby village. His benign intervention and its rewards ended in his elevation to a bishopric. Thereafter, beyond the article's horizon, his bent toward a mission among the poor could find ample expression, certainly better funded, as was indicated in my commentary on Items 20-21 in the third Table, above. ${ }^{62}$ There was thus nothing novel in his story. Abraham could play such a successful part thanks to the money he could command in the usual way of the Haves, though in his case, vicariously.

Besides these two texts, Brown looks also to the Elder Simeon, initiator of the stylite life; effectually it ended with his successor, Daniel, and Daniel's successor, Simeon the Younger. Giving themselves to the publicity of their penitential routines, building their platforms high in the air and positioning themselves near or in major cities, they succeeded in securing the awe-struck reverence of the secular world around them; so they might indeed be listened to. It needs no pointing out, however, that ascetics characteristically began their lives with their prayers screened from observation; for, in obedience to Matthew 6, good Christians in worship were not to draw attention to what they were doing, like the hypocrites. They should

work of two years later, Le patronat, for example, at 426 (patrocinium reached its high point in the fourth century, as the Egyptian texts illustrate); and $(428,462-64,471)$ threats to it from the military were resisted (if ineffectually) by imperial legislation. For more evidence, see further $\operatorname{Cod}$. Theod. 11.24.1-6 and MacMullen, Corruption, 85-86 and chapter $2 \S 3$ at various other points.

${ }^{60}$ On the money-relations between the working masses and persons of power, see MacMullen, Corruption, Appendix C and "Soldiers in Cities in the Roman Empire," Revue des Études Militaires Anciennes 3 (2006) 125-30; on the role of the Church, see above, nn. 43, 52.

${ }^{61}$ Above, at note 46 and the succeeding paragraph; further, Harmand, Patronat, 484, speaking of "large villages each with many landowners" - as Brown notices and goes on to add without evidence that the Haves of Libanius' type were idle feckless patrons and the soldiers, "sensitive to the needs of villagers" ("Rise and Function," 85-86) and caring toward the peasantry (!).

${ }^{62}$ Above, n. 43; and notice Harmand, Patronat, 486, that the Church in the later Roman empire mostly took over the civic impulse of social support, philanthropy, generosity - as is outlined above. 
rather retreat into "a secret place," such a place as an abandoned tomb, a cistern, a hermit's cell or a monk's.

And where it was physically possible, they should support themselves by the work of their hands. To do so was a part of their asceticism, as the obligation was a tenet of the ascetic movement. Obedient to St. Paul's example, it was defended in many passages by a prominent source for Brown's essay, Theodoret of Cyrrhus. It was defended, too, by another bishop, one of its devoted historians, Palladius, lashing out at "busybodies infected with misdirected piety, with their ill-judged pretexts falling short of disengagement from the world (apatheia) and in consequence fostering interfering, meddlesome busy-ness and the rejection of concerns that served their own best interests." ${ }^{163}$ What justifies the choosing of these three stylite saints to serve as referents in some 60 of the 95 footnotes in the article that instance holy men at all? Why should the same three serve as an explanatory "model" $(91,92)$, where so clearly they offered themselves rather as theatrical outliers? A central role for ascetics as mediators (4\% of the mentions in all 829 of the three Tables, above) can't be supported even by drawing on a data-base many times larger than anything sampled in the article.

Ascetics seem in fact to behave in the manner of that reprobated sect unique to Syria, "Messalians" in Syriac, "those who pray," "the Supplicants." 64 In the Messalians' insistence on a total devotion to penitence, freed as they thought from the need to supply their own wants and thus, dependent on their supporters, they were seen by others as an "ascetic heresy" (84) - certainly not in the ascetic movement's main stream. Additionally, only one of them, Simeon the Elder, can offer support to Brown's picture of holy men in action, if their profiles may be trusted; for the Elder Simeon with Theodoret does indeed score high on a mediator scale (items 23 and 24 in Table 3), but the other two stylites together afford only two mentions in these categories. In sum, only by selection, distortion and suppression of evidence can the holy man be presented principally or even significantly as a mediator. ${ }^{65}$

A last weakness, perhaps the most obvious in "Rise and Function," appears in its comment on the prominence of miracles in Theodoret. The bishop indeed has much to say about them; he recalls his own childhood raised among them; yet Brown's comment concludes in the flat declaration, "The miracle is felt to be secondary ... often no more than a pointer" (87). How so? Again, a declaration: miracles smack of "magic" (96), to be dismissed as "bizarre . . folklore" (89); they

${ }^{63}$ Palladius' prologue $\S 8,2: 12$ [in the Greek text Butler uses and indicates, $P G$ 34.1003], my own translation of an extravagant bit of rhetoric.

${ }^{64}$ On Messalianism, see, for example, Theodoret's opposition, Hist. relig. 10.3, and in general, Pierre Canivet, Le monachisme syrien selon Théodoret de Cyr (Paris: Beauchesne, 1977) 221, 224, and Escolan, Monachisme, chapter 3 and elsewhere.

${ }^{65}$ In support of a mediating role for holy men across my whole data-base, there are 33 mentions of mediating roles $(23,24)$ out of 829 mentions $(4 \%)$; compare the 40 mentions for control over wind, weather, and water $(17,18)$ or 78 mentions for prediction and second sight $(10,11)$. 
belong to "primitive" times and beliefs $(82,99)$; or, like Simeon the Elder himself, they belong to centuries in which Gibbon saw only decay (81). "Altogether, we get a very wrong impression if we look only at the miraculous element in the holy man's relations with his clients" (98). Stories of thaumaturgy are the occasion of "a strain placed on the credulity" of ourselves in our enlightened times (96); for it is of course not easy for us to accept the demonic causation of all fleshly ills that Simeon and the unenlightened took for granted. ${ }^{66}$

Instead, we are directed to the holy man's routine of devotion to all those around him, a devotion perceived as a sort of life-long consultancy throughout the "twenty-four hours of the day" (81). He must ever assure good relations among his "clientele" $(92,96)$ through his "labor" and "sweat" $(94)$, his "work" (93) that was indeed "hard work" $(81,86,94)$, a "hard business" (80). Daniel's "reputation," for example, "owes little to his feats as a thaumaturgist" (92). Holy men accepted their role as any good "professional" must $(93,97,100)$, obedient to expectations; and "what men expected of the holy man coincides with what they sought in the rural patron" (87).

To illustrate the professionalism of the holy man, "Rise and Function" follows a religious tourist to the home of the ascetic John, in whom the bishop-historian Evagrius in Alexandria had expressed an interest; so Evagrius' young friend Palladius obediently journeys up-Nile to the site, to seek a report. There in the hostelry, open only on weekends (where later there was a grander one built, to accommodate a hundred visitors), he awaited his turn to speak to the holy man and pose his questions - since John, though a healer, was even better known for his gifts of prophecy. Palladius inquired about his brother and sister: would they enter a monastic life? Would his father recover health? And what of his own future? On all points, he was comforted by John's predictions. ${ }^{67}$

Brown, however, re-writes this narrative (93) to provide "a hall to house one hundred consultants at a time," where in fact that facility was not yet built nor was there ever more than one consultant, John, and continues with a reference to holy men's "well-furnished consulting rooms" discovered by archeologists. The picture thus is of some care-giver in the National Health, some "true professional" who could "keep his wits about him." Yet in truth, John performed exactly as wonted; and in the Table, this prophetic power (10) is especially often mentioned. Everything in the sources is thus, so to speak, normal - which "Rise and Function" suppresses in order to support a different profile, more asserted than founded in the sources.

The picture of the holy man in "Rise and Function" is at all these many points and others besides quite incompatible with my own, offered above. Let me hope

${ }^{66}$ Of the uneasiness so often occasioned among modern scholars by the ancients' belief in miracles, see a few examples above at n. 33 .

${ }^{67}$ On John of Lycopolis, see Palladius, in Nicolas Molinier, Histoire Lausiaque, Introduction, traduction et notes (Bégrolles-en-Mauges: Abbaye de Bellefontaine, 1999) 151-59, esp. at 35.8-13; Greek text, Festugière, Historia monachorum (1971) 9-35, and trans., Moines d'Orient (1964) 9-28; regarding hostelries, see above at n. 43; in contrast, Brown, "Rise and Function," 93. 
that, if control of the data-base is made sufficiently accessible, comparison of the two will allow a good choice between them.

\section{Data-Base Appendix}

After each entry follows the profile of the ascetic(s) treated in the Coptic (in translation), Greek, or Latin text, giving citations and, in parentheses, the relevant Item-number in my Tables; so, for example, at 1.4 in Theodoret's Hist. relig. will be found mention of divine punishment of Bad Persons whom the saint encounters, expressed as $1.4(22)$.

Alexander Akoimetos (Syriac), Vie d'Alexandre Acémète (ed. Émile de Stoop; PO 6; Paris: Firmin-Didot, 1911) 644-705; Greek text, Historia monachorum in Aegypto. Édition critique du texte grec et traduction annotée (ed. André-Jean Festugière; Brussels: Société des Bollandistes, 1971) 9-35, and Les Moines d'Orient (trans., André-Jean Festugière; 4 vols. in 7; Paris: Cerf, 1961-1965) (1964) 4, 1:9-28; Englished by Daniel Caner, Wandering, Begging Monks: Spiritual Authority and the Promotion of Monasticism in Late Antiquity (Berkeley: University of California Press, 2002) 250-80.

The profile of Alexander "the Never-sleeping": 6 (21); 13 (16); 16 (2); 19 (20); 22 (21); 27 (21); 32 (10); 33 (20); 34 (22); 35 (20); 39 (21); 45 (20); 46 (9); 46 (11); 46 (16).

Amélineau, see Macarius.

Anthony's Life by Athanasius, in Athanase d'Alexandrie, Vie d'Antoine; introduction, texte critique, traduction, notes (ed. Gerhardus Johannes Marinus Bartelink; Paris: Cerf, 1994); gingerly acceptance of this authorship by Harmless, Desert Christians, 112-13. The Latin translation by Evagrius has been Englished by Caroline White, Early Christian Lives (London: Penguin, 1968) 70-170; the Greek, Englished by Robert C. Gregg, in Athanasius, The Life of Antony and the Letter of Marcellinus (Mahwah, NJ: Paulist Press, 1980) 29-100.

The profile of Anthony in Athanasius' Life: 14.5 (1); 48.3 (2); 48.4 (1); 50.9

(13); 54.4 (18); 56-57.1 (1); 57.3 (3); $58.1-5$ (3); 59.2 (11); 60.6 (12); 61.3

(3); 62.1 (11); 63.3 (2); 64.5 (2); 70.2 f. (1); 71.2 (2); 80.4 (1); 82.4 (11); 84.1

(1); 86.7 (22); 87.2-4 (21); 89.2 (10).

Apophthegmata patrum, as The Alphabetical Sayings of the Desert Fathers (trans. John Wortley; Yonkers: St. Vladimir's Seminary Press, 2014), in what the translator also calls "the alphabetical collection," constituting the earliest of several collections all called Apophthegmata patrum, as he explains, pp. 16-17 and again in his Palladius of Aspuna, The Lausiac History (Collegeville, PA: Liturgical Press, 2015) xiv. The same editor also translated "the systematic collection" as The Book of the Elders: Sayings of the Desert Fathers (Collegeville, PA: Liturgical Press, 2012). There are earlier translations both in English and French, with an old text in Greek, $P G$ 65.71-440, and in 
Latin, Vitae patrum V: Verba seniorum in PL 73.851-1024; an overview in Harmless, Desert Christians, 167-86.

The Profiles of holy men among the Egyptian monks: pp. 34 (13); 61 (13); 78 (12); 79 (2); 85 (10); 90 (2); 95 (10); 121 (13); 129 (2); 176 (3); 184 (3); 203 (7); 204 (22); 208 (2); 213 (1); 217 (18); 218 (2); 271 (13); 299 (22).

Chariton, the anonymous Life, in Ascetic Behavior in Greco-Roman Antiquity. A Sourcebook (ed. Vincent L. Wimbush; trans. Leah Di Segni; Minneapolis: Fortress Press, 1990).

The Profile of Chariton (b. Iconium ca. 275): 403-04 (22); 409 (9); 409 (1).

Cyril of Scythopolis, as Kyrillos von Skythopolis (ed. Edouard Schwartz; Leipzig: J. C. Hinrichs, 1939); as [Cyril of Scythopolis:] Lives of the Monks of Palestine (trans., Richard M. Price; Kalamazoo, MI: Cistercian Publications, 1991).

The profile of Cyril's holy man (page and line-number in Schwartz): 20.25 (3); 21.15 (1); 22.15. (2); 23.5 (13); 27.20 (20); 29.10 (22); 31.20 (22); 34.25 (1); 35.10 (11); 36.5 (4); 36.20 (2); 39.5 (17); 57.5 (18); 66.10 (18); 70.5 (22); 75.25 (2); 76.1 (2); 77.25 (2); 81.20 (22); 89.25 (16); 94.25 (18); 96.10 (13); 107.15 (13); 109.25 (17); 130.5 (22); 135.10 (10); 136.15 (3); 137.5 (20); 138.15 (20); 145-147 (21); 160.20 (8); 164.5 (3); 164.15 (3); 167.10 (18); 168.15 (18); 171.5 (3); 177.10 (21); 212.10 (13); 215.15 (13); 218.5 (2); 219.15 (11); 228.10 (3); 228.20 (1); 232.5 (13); 232.30 (18); 242.15 (1); 242.35 (17); 247.10 (1); 355.5 (1); 355.15 (2); 356.1 (3).

Daniel the Stylite's biography in Hippolyte Delehaye, Les Saints Stylites (Brussels: Société des Bollandistes, 1923) 1-94; translated as "Saint Daniel the Stylite" in Three Byzantine Saints: Contemporary Biographies Translated from the Greek (ed. and trans. Elizabeth Dawes and Norman H. Baynes; Oxford: Blackwell, 1948) 7-71.

The profile of Daniel the Stylite: 20 (3); 20 (1); 27 (22); 29 (2); 31 (3); 33 (2); 36 (2); 37 (2); 38 (4); 39 (22); 40 (2); 44 (1); $45-46$ (10); 49 (22); 58 (1); 59 (22); 59 (2); 65 (10); 68 (10); 74 (3); 74 (1); 75 (22); 76 (22); 77 (3); 79 (3); 81 (13); 82 (4); 83 (23); 85 (1); 86 (3); 87 (3; 88 (3); 89 (6); 90 (9); 90 (23); 91 (10); 93 (10); 94 (10); 97 (2).

Evagrius Scholasticus, his Ecclesiastical History with introduction, critical notes and indices (ed. Jean Bidez and Léon Parmentier; Amsterdam: A. M. Hakkert, 1964); Englished by Michael Whitby, The Ecclesiastical History of Evagrius Scholasticus; translated with an introduction and notes (Liverpool: Liverpool University Press, 2000).

The Profiles of holy men: Barsanuphius 4.33 (1); Simeon "Holy Fool" 4.33 (10); 4.34 (22); Simeon Stylites the Younger 6.23 (1); 6.23 (2); 6.23 (3); 6.23 (10); 6.23 (13); and Zosimas 4.7 (10); 4.7 (9); 4.7 (5); 4.7 (13). 
Gregory the Thaumaturge's biography by Gregory of Nyssa, in Pierre Maraval, Grégoire de Nysse: Éloge de Grégoire le Thaumaturge. Éloge de Basil, traduction et notes (Paris: Cerf, 2014); also Luigi Leone, Vita di Gregorio Taumaturgo: traduzione, introduzione e note (Roma: Città nuova, 1988); Englished by Michael Slusser, Saint Gregory Thaumaturgus: Life and Works (Washington, D.C.: Catholic University of America Press, 1998).

The Profile of Gregory of Nyssa's holy man, the "Thaumaturge": 15-17 (22); 40 (19); 46 (1); 46 (3); 47 (23); 47 (24); 48 (19); 50 (24); 52 (18); 59 (19); 65-67 (21); 76 (22); 77 (2); 78 (1); 89 (11); 99 (3).

Hilarion's biography by Jerome in Jérôme, Trois vies de moines (Paul, Malchus, Hilarion / Jérôme) (ed. Pierre Leclerc, Edgardo Martin Morales, and Adalbert de Vogüé; Paris: Cerf, 2007); Englished, in Carolinne White, Early Christian Lives (London/New York: Penguin, 1998) 89-115.

The profile of Jerome's Hilarion: 7.4 (4); 8.8 (3); 9.3 (5); 9.6 (3); 10.4 (2); 10.11 (2); 11.1 (2); 11.11 (22); 12.10 (2); 13.9 (2); 14.5 (2); 15.1 (1); 17.9 (21); 19.1 (1); 22.4 (18); 24.4 (22); 26.3 (1); 28.4 (13); 29.3 (17); 29.12 (22); $30.6(1)$.

Historia monachorum in Aegypto, anonymous: ed. André-Jean Festugière and separate trans., Enquête sur les moines d'Égypte, in his Moines d'Orient (both, Paris: Cerf, 1964); text and translation together, André- Jean Festugière, Historia monachorum in Aegypto (Brussels: Société des Bollandistes, 1971). For the problem of some duplication in the dependent Lausiac History, see below, Palladius. For an English version, see Norman Russell, Lives of the Desert Fathers (Piscataway, NJ: Anglican Sisters of the Love of God, 2009), with a bibliography pp. 6-7, on the different versions.

The profile of many monks in Egypt: Praef. 9 (1) and 9 (9); chap. 1.2 (10); 1.8 (10); 1.10 (10); 1.12 (1); 1.12 (5); 1.14 (11); 1.16 (3); 1.64 (10); 2.6 (1); 4.3 (13); 5.7 (9); 6.1 (9); 6.1 (10); 6.1 (1); 6.2 (22); 8.2 (9); 8.7 (1); 8.36 (23); 8.37 (22); 8.40 (20); 8.46 (20); 8.48 (10); 9.1 (13); 10.1 (9); 10.1 (1); 10.20 (12); 10.31 (16); $10.34 f$. (22); 12.7 (13); 12.15 (20); 15.1 (9); 16.1 (11); 19.1 (9); 20.12 (13); 21.1 (9); 21.1 (1); 21.15 f. (13); 22.4 (2); 22.9 (22); 22.7 (12); $26.1(9) ; 26.1(1)$.

Hypatius' Life by Callinicus, in Vida de Hipacio, Callinico. Introducción, traducción (ed. Ramon Teja; Madrid: Trotta, 2009); or Gerhardus Johannes Marinus Bartelink, Callinicos. Vie d'Hypatios. Introduction, texte critique, traduction et notes (Paris: Cerf, 1971).

The profile of Callinicus' holy man Hypatius: 4.8f. (3); 6.7 (23); 9.6 (3); 12.2 (3); 12.10 (3); 15.2 (3); 18.1 (21); 20.3 (20); 22.1 (21); 22.5 (1); 22.7 (5); 22.10 (1); 22.11 (3); 22.14 (1); 22.15 (3); 22.21 (1); 22.21 (8); 28.5f. (3); 28.27f. (3); 28.32 (24); 28.47 (1); 28.50-56 (2); 31.1-3 (21); 32.19 (10); 36.3 (21); 38.4f. (5); 38.10 (8); 38.13f. (1); 40.1f. (2); 40.5 (2); 40.8-16 (2); 40.24 (19); 43.21f. (22); 44.2 (2); 44.15-19 (22); 44.21-23 (2); 44.24 (2); 44.27-29 (5); 44.37 (1); 46.4 (17). 
John of Ephesus, Lives of the Eastern Saints: Syriac Text Edited and Translated by Ernest Walter Brooks part I, in PO 17 (Paris: Firmin-Didot, 1923) 1-304, and part II in PO 18 (1924) 513-698, the following Profile references being to page numbers. [In part III (1926) there is no relevant evidence.] All three parts have been reprinted with unchanged pagination (Paris: Brepols, 2003 [1923-1925]).

The Profile of John of Ephesus' many holy men: p. 5 (1); 7-8 (22); 8-9 (21); 9 (22); 10 (22); 11 (21); 11 (5); 12 (2); 12 (4); 14 (17); 14 (2); 15 (2); 15 (22); 16 (21); 17 (13); 17 (9); 18 (18); 20 (22); 24 (22); 25 (3); 26 (21); 29 (22); 30 (22); 34 (9); 41 (1); 43 (1); 57 (2); 63 (7); 64-68 (1); 70 (4); 71 (1); 73 (21); 74-75 (22); 79-80 (11); 108-109 (1); 117 (1); 223 (2); 223 (1); 300 (22); [part II] 581 (21); 596 (21); 604-605 (21); 613 (2); 613-614 (1); $615(20)$.

Macarius "the Great," in Émile Amélineau, Histoire des monastères de la Basse Égypte. Vies des saints Paule, Antoine, Macaire, Maxime et Domèce Jean le Nain, etc. Texte copte et traduction (Paris: Ernest Leroux, 1894) 46-117.

The profile of Macarius "of Scete," called "the Great": page 88 (1); 90 (1); 91f. (3); 91-92 (7); 91-92 (6); 91-92 (2); 102 (11); 98 (3); 104 (21); 104 (1).

Pachomius and his successor Theodore, in Armand Veilleux, La vie de saint Pachôme selon la tradition copte (Bégrolles-en-Mauges: Abbaye de Bellefontaine, 1984) 21-259 [original French translated into English, 1980].

The profile of Pachomius and Theodore: $\$ 10$ (21); 20 (13); 41 (3); 42 (23); 43 (2); 43 (11); 44 (2); 45 (1); 109 (2); 110 (2); 111 (2); 112 (3); 150 (1); 151 (1); 152 (3); 153 (3); 154 (3); 180 (10).

Palladius, The Lausiac History of Palladius (ed. Cuthbert Butler; Cambridge: Cambridge University Press, 1898); of date 420, see Nicolas Molinier, Histoire Lausiaque, Introduction, traduction et notes (Bégrolles-en-Mauges: Abbaye de Bellefontaine, 1999) 26 (date) and 56-222, the translation; Englished by William Kemp Lowther Clarke (London/New York: SPCK, 1918); more recently by Robert T. Meyer (Westminster/ London: Longmans, Green, 1965). The church historians Socrates (4.23) and Sozomen (3.14; 6.20, 28-34) drew heavily on Palladius, as also did Rufinus of Aquileia for a Latin version (PL 21:387-462; see Molinier 27). In Palladius' 71 chapters are nine individuals who are also profiled in the Historia monachorum in Aegypto (see above). Since the duplication between Palladius and the Monks in Egypt is, however, so incomplete, here, all 71 chapters of the text are tallied. Only a minority yield anything relevant to my Tables.

The profile of Palladius' holy men: 8.6 (12); 12.3 (3); 17.2 (10); 17.2 (1); 17.3 (11); 17.13 (2); 18.10 (13); 18.11 (1); 18.21 (3); 18.22 (2); 18.27 (8); 19.11 (1); 22.9 (2); 23.5 (13); 24.1 (1); 32.1 (10); 35.2 (10); 35.13 (10); 36.5 (6); 36.5 (2); 39.4 (1); 40.2 (21); 44.3 (1); 44.3 (2); 48.2 (13); 50 (22). 
Paphnutius' accounts in Coptic, in Tim Vivian, 'Histories of the Monks of Upper Egypt' and 'The Life of Onnophrius' by Paphnutius with 'A Discourse on Saint Onnophrius' by Pisentius of Coptos, Translated with Introduction (Kalamazoo, MI: Cistercian Publications, 2000) 73-141.

The profile of various monks: $\$ 5$ (21); 27 (11); 31 (21); 46 (8); 46 (24); 53 (6); 75 (11); 84 (16); 86 (21); 88 (21); 90 (1); 98-100 (13); 101 (10); 103f. (3); 105 (4); 108 (7); 108 (1); 111 (22); 111-112 (5); 116 (3); 117 (8); 118 (15); 119f. (21); 122 (15); 123 (5); 124-126 (4); 124-126 (7); 125f. (4); $127-$ 129 (2); 131 (18); 132-134 (18); 136 (9); 13 (21).

Simeon Stylites the Elder: the Syriac biography Englished in Robert Doran, The Lives of Simeon Stylites (Kalamazoo, MI: Cistercian Publications, 1992) 103-98, in the edition dated to 473 (pp. 36, 50), noting its character as an "apologia" (53). It is important not to rely on Hans Lietzmann's edition (1908) of the sixth-century British Museum text, see Delehaye, Saints stylites vi. It is on this of 1908, however, and its German translation by Heinrich Hilgenfeld that Peter Brown's article relies, where the chapter/verse numbers also differ from the earlier Vatican text on which Doran relies (Brown p. 90/ Hilgenfeld p. $117 \S 70=$ Doran $163 \S 82,119 \S 72=165 \S 85,136 \S 93=137$ $\$ 57$, etc.). Another brief Life by Antonius, translated by André-Jean Festugière, Antioche païenne et chrétienne. Libanius, Chrysostome et les moines de Syrie (Paris: Boccard, 1959) 493-506, is Englished by Doran, Lives, 87-100; it contains little on miracles except, as Doran notes (97 n. 16), "later additions" published by Hans Lietzmann. As to the Life by Theodoret, for purposes of profiling it is considered only as it appears above in this author's Historia religiosa along with other saints (and therein, chapter 26).

The Profile of the Stylite (Syriac): 6 (2); 7 (20); 9 (21); 11 (20); 17 (22); 22 (16); 29 (20); 33 (3); 34 (3); 35 (3); 36 (2); 37 (1); 38 (11) 38 (3); 39 (22); 56 (23); 56 (22); 57 (21); 57 (22); 60 (22); 61 (13); 63 (13); 64 (18); 65 (9); 69 (22); 70 (17); 71 (17); 72 (17); 73 (22); 74 (18); 75 (18); 77 (23); 77 (21); 78 (1); 79 (3); 80 (3); 81 (3); 82 (1); 83 (3); 84 (3); 85 (18); 86 (19); 88 (13); 89 (2); 90 (13); 91 (3); 92 (22); 100 (22); 101 (20); 105 (10); 106 (1); 106 (23).

Simeon the Younger's anonymous Life in Paul van den Ven, La vie ancienne de S. Syméon stylite le Jeune (521-592) 2 vols.: 1: Introduction et texte grec (Brussels: Société des Bollandistes, 1962) and 2: Traduction et commentaire (1970).

The profile of Simeon the Younger: Praef. (1); 1 (9); 14 (22); 20 (3); 21 (2); 42 (2); 43 (2); 44 (2); 45 (3); 46 (7); 48 (2); 49 (2); 50 (1); 51 (13); 52 (13); 53 (5); 54 (3); 55 (2); 56 (1); 57 (11); 58 (3); 59 (17); 60 (22); 61 (1); 64 (1); 66 (3); 67 (1); 68 (13); 69 (3); 70 (1); 71 (10); 72 (21); 72 (22); 73 (2); 74 (3); 75 (3); 76 (3); 77 (21); 78 (19); 79 (13); 80 (5); 80 (3); 81 (3); 82 (2); 84 (6); 85 (1); 86 (2); 87 (2); 88 (3); 89 (3); 92 (3); 95 (1); 96 (1); 97 (18); 101 (3); 101 (3); 102 (3); 105 (10); 111 (3); 113 (1); 114 (3); 115 (3); 116 (22); 117 (5); 118 (4); 118 (2); 119 (3); 120 (3); 122 (20); 123 (20); 131 (22); 123 (1); 136 (3); 137 (2); 137 (5); 138 (3); 139 (2); 138-140 (1); 140 (4); 141 (3); 142 (3); 143 (3); 144 (7); 145 (5); 146 (6); 147 (2); 148 (8); 149 (18); 150 
(3); 151 (2); 152 (3); 153 (3); 154 (3); 155 (6); 156 (5); 158 (3); 158 (22); 163 (3); 167 (3); 168 (3); 170 (11); 172 (17); 173 (10); 174 (11); 175 (11); 176 (22); 177 (2); 178 (13); 179 (11); 180 (5); 182 (13); 183 (13); 184-185 (13); 187 (10); 188 (5); 190 (3); 191 (6); 192 (6); 193 (6); 195 (3); 196 (7); 197 (3); 198 (3); 199 (3); 200 (3); 201 (11); 203 (10); 207 (2); 212 (3); 213 (5); 213 (3); 214 (2); 214 (22); 215 (11); 216 (11); 217 (18); 218 (3); 219 (2); 220 (3); 223 (11); 225 (22); 226 (3); 227 (2); 28 (11); 229 (2); 230 (5); 230 (5); 231 (1); 232 (3); 233 (11); 234 (3); 236 (17); 237 (11); 238 (13); 239 (11); 241 (5); 242 (3); 244 (6); 245 (3); 246 (3); 247 (3); 248 (3); 249 (3); 250 (5); 251 (3); 252 (1); 253 (1); 254 (1).

Theodore of Sykeon's biography by George of Sykeon, in Vie de Théodore de Sykeon 1. Texte, grec; 2, traduction (André-Jean Festugière; 2 vols.; Brussels: Société des Bollandistes, 1970), the saint d. 613; see also an English translation by Dawes and Baynes, Three Byzantine Saints, 88-185.

The profile of Theodore of Sykeon: 14 (17); 18 (2); 26 (3); 26a (1); 26a (8); 30b (13); 31 (3); 34 (22); 35 (2); 36 (14); 42 (11); 43 (2); 44 (2); 45 (8); 45 (18); 46 (2); 51 (18); 52 (18); 53 (18); 55 (19); 56 (18); 57 (10); 59 (1); 60 (20); 61 (1); 61 (22); 64 (6); 65 (3); 67 (6); 68 (3); 69 (22); 70 (11); 71 (2); 72 (7); 76 (21); 76 (22); 80b (1); 81 (3); 83 (5); 84 (2); 85 (3); 86 (2); 87 (2); 88 (2); 89 (2); 80 (10); 91 (3); 92 (20); 93 (2); 93 (4); 94 (2); 96 (6); 96 (3); 97 (2); 98 (8); 99 (8); 101a (18); 101a (14); 102 (3); 103 (2); 104 (15); 107 (3); 107 (3); 108 (3); 109 (3); 110 (3); 110 (6); 111 (3); 112 (3); 113 (3); $115 \mathrm{a}(1) ; 115 \mathrm{~b}$ (14); $118 \mathrm{~b}(14) ; 119$ (10); 120 (10); 121 (3); 122 (5); 123 (2); 123 (13); 129 (2); 131 (1); 132 (2); 138 (2); 140 (2); 141 (18); 143 (3); 144 (17); 145 (14); 145 (8); 145 (24); 145 (1); 147 (21); 148 (21); 148 (22); 149 (22); 150 (23); 151 (21); 151 (22); 153 (10); 154 (1); 154 (3); 156 (4); 156 (1); 156a (5); 156a (3); 157 (2); 157 (20); 158 (1); 159 (3); 159 (11); 159 (2); 159 (2); 160 (8); 160 (1); 161 (1); 162 (2).

Theodoret's history of the Church, trans. in Histoire ecclésiastique/Theodoret de Cyr; Greek text edited by Leon Parmentier and Günther Christian Hansen (3rd ed.; GCS, NF 5; Berlin: Akademie, 1998), notes and review by Jean Bouffartigue; introduction by Annick Martin; translation by Pierre Canivet (Paris: Cerf, 2006-2009). See relevant parts below in "Brief mentions."

Theodoret, Historia religiosa (also called by the author, $\$ 10$, "Historia philothea"), in Pierre Canivet and Alice Leroy-Molinghen, Théodoret de Cyr, Histoire des moines de Syrie 'Histoire philothée', 2 vols.; 1, Introduction, texte critique, traduction, notes (Paris: Cerf, 1977-79); 2 (1979) with uninterrupted chapter numeration but with its own pagination; also an English translation by Richard M. Price, History of the Monks of Syria by Theodoret (Kalamazoo, MI: Cistercian Publications, 1985).

The profile of Theodoret's holy men: 1.4 (22); 1.4 (18); 1.6. (19); 1.7 (21); 1.8 (22); 1.8 (7); 1.11 (14); 2.18 (3); 2.19 (1); 2.19 (3); 2.20 (3); 2.21 (10); 3.7 (13); 3.8 (17); 3.9 (2); 3.9 (9); 3.22 (2); 5.8 (24); 6.2 (13); 6.4 (9); 6.5 (24); 6.6 (1); 6.10 (13); 7.3 (11); 8.9 (22); 8.11 (8); 8.13 (9); 8.13 (24); 8.14 
(14); 9.4 (2); 9.5 (3); 9.7 (3); 9.9 (2); 9.10 (2); 9.12 (22); 9.14 (3); 9.15 (1); 10.4 (17); 10.7. (18); 11.4 (1); 11.4 (4); 13.9 (3); 13.11 (2); 13.13 (2); 13.14 (16); 13.15 (10); 13.16. (4); 13.17 (3); 14.3 (1); 14.3 (3); 14.4 (22); 15.2 (22); 15.3 (22); 16.2 (1); 16.3 (24); 17.3 (23); 17.8 (23); 21.14 (7); 21.14 (1); 21.14 (7); 21.17 (10); 22.3 (1); 22.5 (13); 24.7 (1); 26.11 (1); 26.11 (12); 26.15 (3); 26.16 (3); 26.17 (9); 26.19 (10); 26.21 (4); 26.22 (9); 26.26 (23); $28.5(9) ; 28.5(8)$.

\title{
Sources not used or used with caution:
}

Jerome's three ascetics' biographies are all suspect. See Christine Mohrmann, "Introduzione" to Bartelink, Vita di Antonio, xliii n. 2; but Hilarion figures also in other sources. His life is listed separately, above. As to the Paul biography, see John Wortley, Alphabetical Sayings, 271; Harmless, Desert Christians, 105; and Timothy D. Barnes, Early Christian Hagiography and Roman History (Tübingen: Mohr Siebeck, 2010) 133, 183 ("total fiction").

\begin{abstract}
Also a poor source, as being so highly rhetorical and morally didactic, the anonymous Syriac Life of Rabbula translated by Robert Doran, Stewards of the Poor: The Man of God, Rabbula, and Hiba in Fifth Century Edessa (Kalamazoo, MI: Cistercian Publications, 2006) 65-105, and 64 on the preferred Greek text, ed. 1865.
\end{abstract}

"Mark the Deacon," Life of Porphyry, dismissed as a sixth-century fabrication by Barnes, Early Christian Hagiography, 260-74, citing various scholars (though the work continues to be used as irresistible).

\section{Brief mentions, in alphabetical order:}

A certain Abraham abbot of a monastery in the vicinity of Aleppo visited by Rabbula, where both the monks and the abbot wrought miracles of healing; see Doran, Stewards, pages 67 (1) and 67 (3); anonymous monks (2) in Regnault et al., above at note 16, p. 352, and in the Apophthegmata patrum, "alphabetical," ed. Wortley 277 (11); Barsanouphius in this abbot's Correspondance 88 (3) and 534 (2), cf. above at nn. 16, 51; also 364 (23) in the same edition; Barses in Theodoret, Hist. eccl. 4.16.1-2 (1) in Pierre Canivet's translation, Histoire ecclésiastique 2 (Paris: Cerf, 2009) 240-42; Chariton, the anonymous Life, in Ascetic Behavior in Greco-Roman Antiquity: A Sourcebook (ed. Vincent L. Wimbush; trans. Leah Di Segni; Minneapolis (Fortress Press, 1990) 396-420, at $\$ 11$ (22); 13 (9); 16 (1); 21 (9); 21 (1); 24 (18); John “of Egypt”" in Theodoret, Hist. eccl. 5.25 [24].24 (10); John, in Rapp, “'For next to God,"” above at note 6, pp. 71-72 (3),

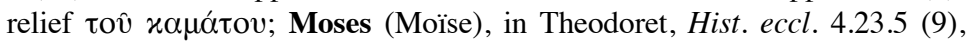

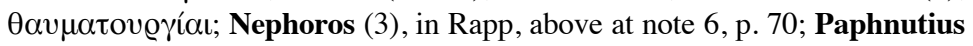
(3), P. Lon. 1926, above at note 3; and Rabbula (3) in the Syriac text translated by Doran p. 87, a cautious wording short of direct healing. 